\title{
Faciologia orgânica da Formação Romualdo (Grupo Santana, Cretáceo Inferior da Bacia do Araripe): caracterização da matéria orgânica sedimentar e interpretação paleoambiental Organic facies analysis of Romualdo Formation (Santana Group, Lower Cretaceous from Araripe Basin): characterization of sedimentary organic matter and paleoenvironmental interpretation
}

\author{
Marília Carvalho Teixeira1, João Graciano Mendonça Filho², Antônio Donizeti de Oliveira², Mário Luis Assine². \\ ${ }^{1}$ Programa de Pós-graduação em Geologia, Faculdade de Geologia, Universidade Federal do Rio de Janeiro - UFRJ, \\ Avenida Athos da Silveira Ramos, 274, Bloco J1, Sala 20 - Cidade Universitária, CEP 21941-916, Rio de Janeiro, RJ, BR \\ (mariliageo08@hotmail.com) \\ 2Laboratório de Palinofácies e Fácies Orgânica, Universidade Federal do Rio de Janeiro - UFRJ, Rio de Janeiro, RJ, BR \\ (graciano@geologia.ufrj.br; donizeti@lafo.geologia.ufrj.br) \\ ${ }^{3}$ Instituto de Geociências e Ciências Exatas, Universidade Estadual Paulista "Júlio de Mesquita Filho" - UNESP, Rio Claro, SP, \\ BR (assine@rc.unesp.br)
}

Recebido em 01 de dezembro de 2015; aceito em 10 de agosto de 2016

\begin{abstract}
Resumo
A reconstrução paleoambiental do Grupo Santana (Neoaptiano-Eoalbiano) é matéria ainda controversa, principalmente no que se refere à influência marinha na sedimentação. Nesse contexto, a análise de palinofácies pode ser utilizada como ferramenta na caracterização de sistemas deposicionais, por meio da determinação de parâmetros palinofaciológicos e organogeoquímicos, baseados na concentração e distribuição dos componentes da matéria orgânica. No presente estudo foram utilizadas técnicas de microscopia em luz branca transmitida e azul/ultravioleta incidente (fluorescência) e métodos geoquímicos para a identificação dos diferentes grupos e subgrupos da matéria orgânica particulada em 58 amostras de uma seção sedimentar da Formação Romualdo (Grupo Santana, Cretáceo Inferior da Bacia do Araripe). As análises permitiram verificar a existência de duas assembleias distintas de componentes orgânicos particulados. A primeira é caracterizada por dominância de matéria orgânica amorfa derivada de tecidos vegetais, com quantidades relativamente elevadas de componentes de origem marinha. A segunda assembleia é caracterizada por dominância do Grupo Fitoclasto, predominando o subgrupo do fitoclasto não opaco não bioestruturado. A subdivisão do perfil litológico estudado em cinco intervalos estratigráficos possibilitou identificar ciclicidade no padrão de suprimento do material orgânico, relacionada a oscilações do nível relativo do mar. Dentre os intervalos estratigráficos identificados, constatou-se indícios da ocorrência de pelo menos duas ingressões marinhas durante a deposição da Formação Romualdo. A primeira marca o estabelecimento de condições relativamente estáveis de deposição da matéria orgânica, sob fácies de caráter mais distal a intermediário, em ambiente de mar epicontinental. A segunda ingressão marinha apresenta tendência de deposição da matéria orgânica sedimentar em condições proximais, mas com elevada influência de componentes de origem marinha, evidenciando um ambiente transicional proximal-distal, possivelmente um ambiente marinho costeiro.
\end{abstract}

Palavras-chave: Bacia do Araripe; Formação Romualdo; Matéria orgânica sedimentar; Palinofácies; Paleoambiente.

\begin{abstract}
The paleoenvironmental reconstruction of the Santana Group (Late Aptian-Early Albian) is a matter of controversy, especially concerning the marine influence on sedimentation. In this context, palynofacies analysis can be applied as an important tool for characterization of depositional systems, through the determination of palynofacies and organic and geochemical parameters, based on the concentration and distribution of the organic matter components. Microscopy techniques in transmitted white light and blue/ultraviolet incident (fluorescence) and geochemical methods were used for the identification of the different groups and subgroups of the particulate organic matter in 58 samples from a sedimentary section of Romualdo Formation (Santana Group, Lower Cretaceous from Araripe Basin). Two distinct assemblies of particulate
\end{abstract}


organic compounds events were identified. The first one is characterized by dominance of amorphous organic matter derived from plant tissues with high amounts of marine origin components. The second assembly is characterized by dominance from phytoclast group, showing high abundance of non-opaque non-bioestrutured phytoclasts. The studied lithologic profile was subdivided into five stratigraphic intervals. This feature allowed the verification of a cyclical pattern in the organic material supply in relation to relative sea level variations. In these stratigraphic intervals, at least two marine ingressions were recognized during the Romualdo Formation deposition. The first one marks the establishment of relatively stable deposition of the organic material, comprising intermediate-distal facies of an epicontinental sea environment. The second marine ingression is recorded by sedimentary organic matter deposited in proximal conditions with high influence of marine-derived components, suggesting deposition in nearshore to coastal settings.

Keywords: Araripe Basin; Romualdo Formation; Sedimentary organic matter; Palynofacies; Paleoenvironment.

\section{INTRODUÇÃO}

A Bacia do Araripe está inserida no contexto geológico das bacias interiores do Nordeste do Brasil, dentre as quais é a que possui maior extensão e a que apresenta história geológica mais complexa. O Grupo Santana (NeoaptianoEoalbiano) - composto, da base para o topo, pelas formações Barbalha, Crato, Ipubi e Romualdo (Neumann e Assine, 2015) - apresenta abundante e diversificado registro fossilífero (Assine, 2007).

A reconstituição paleogeográfica do Grupo Santana é matéria ainda controversa, principalmente no que se refere à ocorrência e ao sentido de influência marinha durante o intervalo Aptiano-Albiano. O estudo dos parâmetros palinofaciológicos e organogeoquímicos, baseados na caracterização dos componentes de origem orgânica, pode ajudar a esclarecer essa questão, visto que tais ferramentas fornecem, principalmente, informações a respeito da relação proximal-distal e das condições paleoambientais de deposição e preservação da matéria orgânica sedimentar (querogênio), permitindo avaliar e comparar as associações dos componentes orgânicos particulados. Nesse contexto, a análise de palinofácies pode ser utilizada como mais uma ferramenta na caracterização de sistemas deposicionais, com base na distribuição espacial e temporal dos intervalos sedimentares.

O presente estudo teve por objetivo a caracterização da matéria orgânica particulada depositada na porção superior do Grupo Santana (Formação Romualdo), bem como a determinação de parâmetros palinofaciológicos e organogeoquímicos, visando uma melhor definição e caracterização paleoambiental, com a finalidade de se identificar os intervalos nos quais teriam ocorrido incursões marinhas.

No presente trabalho, foram utilizadas técnicas de microscopia em luz branca transmitida e azul/ultravioleta incidente (fluorescência) e métodos geoquímicos para a identificação dos diferentes grupos e subgrupos de componentes da matéria orgânica particulada. As informações adquiridas por essas técnicas foram avaliadas no amplo contexto dos fatores gerais que controlam a sedimentação, distribuição e preservação da matéria orgânica. As classificações mais atuais da matéria orgânica sedimentar (Tyson, 1995; Mendonça Filho, 1999; Menezes et al., 2008; Mendonça Filho et al., 2012) são fundamentadas principalmente no caráter morfológico dos componentes, incorporando também as grandes áreas de proveniência das partículas (derivação biológica e ambiente sedimentar). Em geral, a classificação dos componentes do querogênio é baseada principalmente em sua aparência e estado de conservação, por meio de observação microscópica.

Para este estudo, adaptou-se o sistema de classificação geral dos principais componentes da matéria orgânica particulada (Tyson, 1993, 1995; Vincent, 1995; Mendonça Filho, 1999; Carvalho, 2001; Mendonça Filho et al., 2010a, 2010b, 2011, 2012), segundo os quais o material orgânico é dividido em três grupos principais (e seus respectivos subgrupos): Fitoclasto, Palinomorfo e Amorfo. A rigorosa subdivisão das categorias do conteúdo orgânico particulado tem a finalidade de identificar qualquer variação quantitativa que poderia estar relacionada aos principais controles na distribuição da matéria orgânica e, assim, utilizar esses fatores na determinação de seu significado paleoambiental.

Os fitoclastos foram primeiro subdivididos em opacos (pretos) e não opacos (de coloração amarelada a marrom muito escura). As partículas opacas são subdivididas principalmente em relação à sua forma e tamanho; já as partículas não opacas são classificadas de acordo com sua morfologia, presença ou ausência de elementos estruturais e diferenças no estado de preservação (Tabela 1).

O Grupo Palinomorfo é dividido em esporomorfos (esporos e grãos de pólen, de origem terrestre), microplâncton de parede orgânica (algas de água doce/salobra e plâncton marinho) e zoomorfos (Tabela 2). A utilização dessa divisão forneceu indicações da proximidade de fontes fluviais e informações sobre tendências transgressivo-regressivas no intervalo litoestratigráfico considerado.

O Grupo Amorfo constitui o restante do material orgânico e é separado dos demais componentes da assembleia por não possuir feições caracteristicamente botânicas, nenhuma estrutura interna organizada e forma inconsistente. A matéria orgânica amorfa (MOA) pode ser internamente homogênea ou heterogênea, hialina (como em resinas) ou não hialina e, dependendo da fonte e do estado de preservação, pode ou não apresentar fluorescência (Tyson, 1995). Esse grupo é subdividido em MOA derivada de fitoplâncton, MOA derivada da atividade bacteriana, produtos amorfos 
da diagênese de tecidos de macrófitas terrestres e resinas de plantas superiores (Tabela 3 ).

\section{LOCALIZAÇÃO DA ÁREA ESTUDADA}

A área estudada está localizada na porção leste da Bacia do Araripe, próxima à localidade de Sobradinho, entre os municípios de Porteiras e Jardim, no extremo sul do estado do Ceará (Figura 1). Os trabalhos de campo, incluindo a coleta das amostras e a elaboração de perfis, foram realizados no âmbito do projeto Análise Estratigráfica do Andar Alagoas nas Bacias do Araripe, Tucano-Jatobá, Parnaíba e Sanfranciscana (Convênio Petrobras/Universidade Estadual Paulista "Júlio de Mesquita Filho" (Unesp) no 0050.0023165.06.4, SAP $\mathrm{n}^{\circ}$ 46.00321584, Rede de Estratigrafia e Sedimentologia). Esse material foi cedido ao Laboratório de Palinofácies e
Fácies Orgânica (LAFO) da Universidade Federal do Rio de Janeiro (UFRJ).

\section{CONTEXTO GEOLÓGICO}

\section{Bacia do Araripe: aspectos gerais}

A Bacia do Araripe está localizada na região de fronteira entre os estados do Ceará, Pernambuco, Piauí e Paraíba, interior do nordeste do Brasil (Figura 1), possuindo aproximadamente $12 \mathrm{mil} \mathrm{km}{ }^{2}$ de área e $1.700 \mathrm{~m}$ de espessura. De acordo com Assine (2007), a gênese e a evolução da Bacia do Araripe estão diretamente relacionadas aos eventos associados ao rifteamento do Gondwana e à abertura do Atlântico Sul, os quais atuaram de maneira diferenciada no interior da região nordeste do Brasil, por meio da reativação de estruturas

Tabela 1. Sistema de classificação detalhado do Grupo Fitoclasto (Tyson, 1995; Vincent, 1995; Mendonça Filho, 1999; Mendonça Filho et al., 2010a, 2011, 2012).

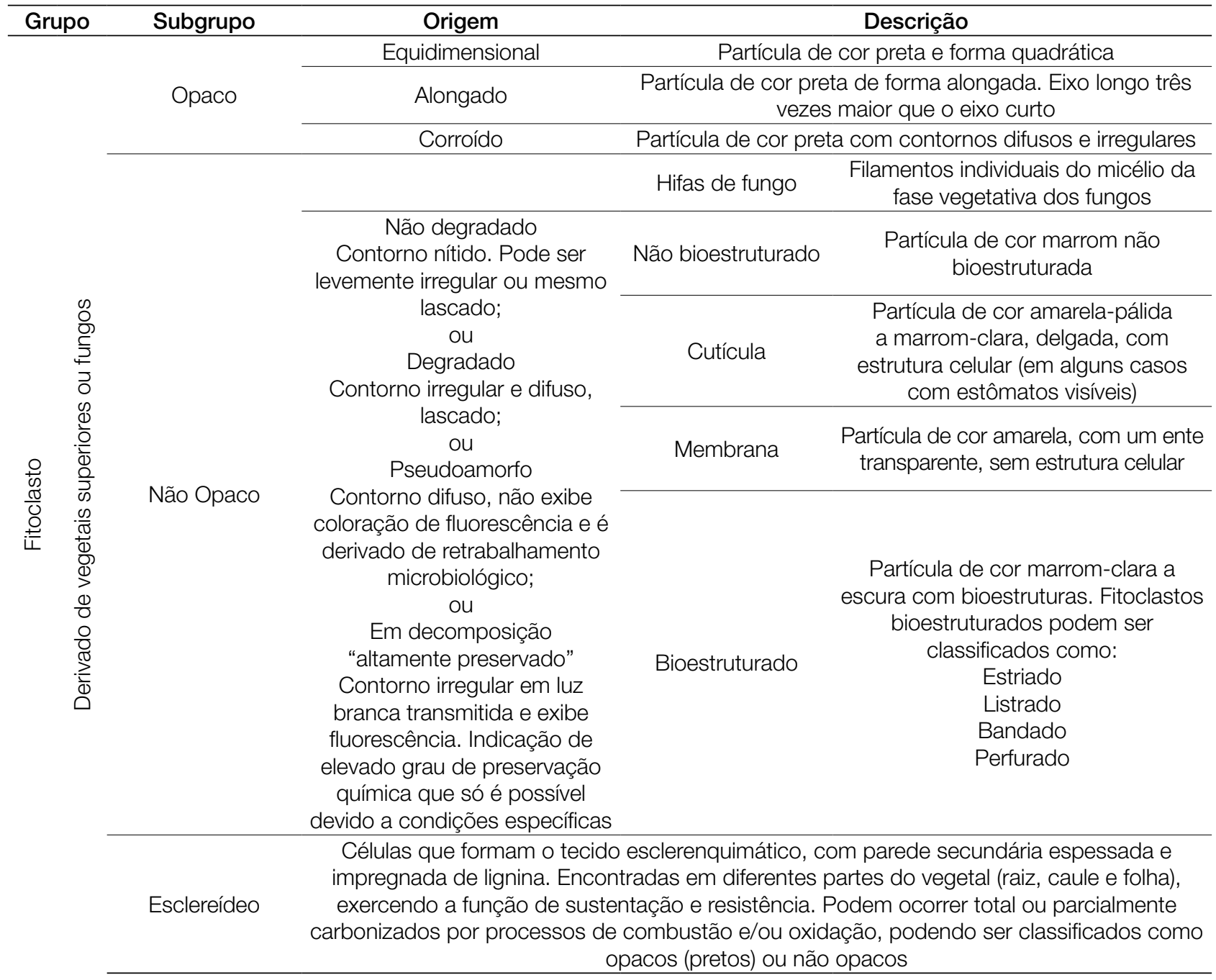


Tabela 2. Sistema de classificação detalhado do Grupo Palinomorfo (Tyson, 1995; Vincent, 1995, Mendonça Filho, 1999; Mendonça Filho et al., 2010a, 2011, 2012).

\begin{tabular}{|c|c|c|c|c|c|}
\hline \multirow[t]{3}{*}{ Grupo } & Subgrupo & Origem & \multirow{2}{*}{\multicolumn{2}{|c|}{$\begin{array}{l}\text { Palinomorfo terrestre } \\
\text { produzido por pteridófitas, } \\
\text { briófitas e fungos }\end{array}$}} & Descrição \\
\hline & \multirow{2}{*}{ 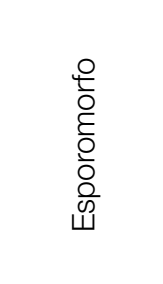 } & Esporo & & & $\begin{array}{l}\text { Forma triangular ou circular, apresentando a } \\
\text { marca trilete ("Y") ou monolete (uma cicatriz). } \\
\text { Ornamentação variada }\end{array}$ \\
\hline & & Grão de pólen & \multicolumn{2}{|c|}{$\begin{array}{l}\text { Palinomorfo terrestre } \\
\text { produzido por } \\
\text { gimnospermas e } \\
\text { angiospermas }\end{array}$} & $\begin{array}{l}\text { Morfologia complexa a simples; usualmente } \\
\text { esférico a subesférico; ornamentação variada; } \\
\text { pode apresentar aberturas }\end{array}$ \\
\hline \multirow{10}{*}{ 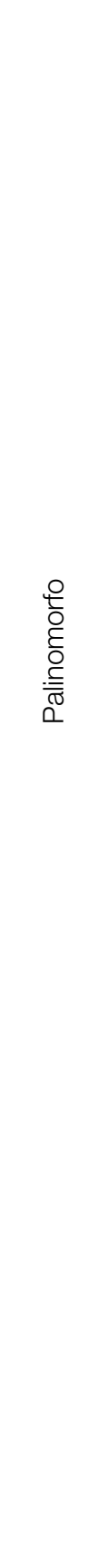 } & \multirow{4}{*}{ 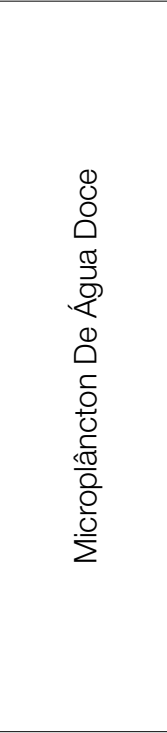 } & Botryococcus & \multirow{3}{*}{\multicolumn{2}{|c|}{$\begin{array}{l}\text { Chlorophyta } \\
\text { (Chlorococcales) }\end{array}$}} & $\begin{array}{l}\text { Colônia globular irregular; tamanho } 30 \text { a } \\
2.000 \text { um; algumas vezes com vários lóbulos; } \\
\text { Carbonífero-Recente }\end{array}$ \\
\hline & & Pediastrum & & & $\begin{array}{l}\text { Algas coloniais, radialmente simétricas; } 30 \text { a } 200 \\
\text { um em diâmetro e com um ou dois cifres no anel } \\
\text { mais externo das células. As células internas } \\
\text { podem ser de forma irregular com espaços entre } \\
\text { elas ou compactadas; Jurássico-Recente }\end{array}$ \\
\hline & & Scenedesmus & & & $\begin{array}{l}\text { Algas verdes coloniais com } 4,8 \text { ou } 16 \text { células } \\
\text { em linha e não móveis. Diferentes formas de } \\
\text { cenóbio são encontradas, tais como: lineares, } \\
\text { costulacoides, elipsoides e ovoides }\end{array}$ \\
\hline & & Zignematacea & & $\begin{array}{l}\text { Chlorophyta } \\
\text { (Zignematales) }\end{array}$ & $\begin{array}{l}\text { São algas verdes filamentosas ou unicelulares, } \\
\text { uniseriadas (não lineares) que produzem } \\
\text { esporos resistentes a acidificação. Os filamentos } \\
\text { são divididos por septos e estão presentes } \\
\text { diversamente na forma de cloroplastos. } \\
\text { A maioria das espécies tem esporos de forma } \\
\text { constante e poucos são polimórficos }\end{array}$ \\
\hline & \multirow{3}{*}{ 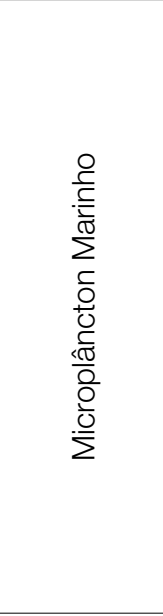 } & Dinocisto & \multicolumn{2}{|c|}{$\begin{array}{l}\text { Restos de cistos } \\
\text { produzidos durante a } \\
\text { parte sexual do ciclo de } \\
\text { vida de dinoflagelados }\end{array}$} & $\begin{array}{l}\text { A principal característica é a paratabulação que } \\
\text { divide a teca do cisto em placas retangulares } \\
\text { ou poligonais separadas por suturas. Três } \\
\text { morfológicas principais: proximados, cavados } \\
\text { e corados. Muitas vezes com uma abertura } \\
\text { (arqueópilo), por meio da qual ocorre o } \\
\text { encistamento; Jurássico- Recente }\end{array}$ \\
\hline & & Prasinófita & \multicolumn{2}{|c|}{$\begin{array}{l}\text { Microfósseis produzidos } \\
\text { por pequenas algas } \\
\text { quadriflageladas }\end{array}$} & $\begin{array}{l}\text { A maioria, como as Tasmanites, é } \\
\text { esférica; diâmetro de } 50 \text { a } 2.000 \text { m; Pré- } \\
\text { Cambriano-Recente }\end{array}$ \\
\hline & & Acritarco & \multicolumn{2}{|c|}{$\begin{array}{l}\text { Cistos fossilizados de } \\
\text { organismos unicelulares. } \\
\text { Não tem status } \\
\text { taxonômico formal }\end{array}$} & $\begin{array}{l}\text { Grupo polifinético de palinomorfos, cujo nome } \\
\text { significa "origem incerta". Organismos de } \\
\text { pequena dimensão (5 a } 150 \text { mm). Ornamentação } \\
\text { e formas variadas; surgiram no Pré-Cambriano, } \\
\text { com auge no Ordoviciano-Devoniano e baixa } \\
\text { diversidade no Meso-Cenozoico }\end{array}$ \\
\hline & \multirow{3}{*}{ 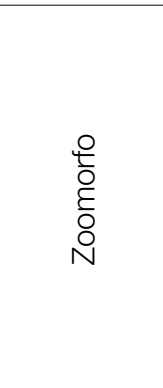 } & Palinoforaminífero & \multicolumn{2}{|c|}{$\begin{array}{l}\text { Película interna que } \\
\text { reveste a carapaça de } \\
\text { foraminifferos }\end{array}$} & $\begin{array}{l}\text { Parede interna quitinosa; marrom; câmaras } \\
\text { menores muitas vezes mais escuras }\end{array}$ \\
\hline & & Escolecodonte & \multicolumn{2}{|c|}{$\begin{array}{l}\text { Elementos dispersos } \\
\text { do aparelho bucal dos } \\
\text { anelídeos poliquetas }\end{array}$} & $\begin{array}{l}\text { Peças bucais compostas por quitina; } \\
\text { Ordoviciano Inferior-Recente }\end{array}$ \\
\hline & & Quitinozoário & \multicolumn{2}{|c|}{$\begin{array}{l}\text { Vesículas em forma de } \\
\text { garrafinhas ocas ( } 30 \text { a } \\
2.000 \mu m) \text {. Afinidade } \\
\text { incerta }\end{array}$} & $\begin{array}{l}\text { Constituem um grupo extinto de organismos } \\
\text { marinhos, microscópicos, dotados de testas } \\
\text { orgânicas de quitina; Ordoviciano-Devoniano }\end{array}$ \\
\hline
\end{tabular}


Tabela 3. Sistema de classificação detalhado do Grupo Amorfo (Tyson, 1995; Vincent, 1995, Mendonça Filho, 1999; Mendonça Filho et al., 2010a, 2011, 2012).

\begin{tabular}{|c|c|c|}
\hline Grupo & Subgrupo & Descrição \\
\hline \multirow{5}{*}{ 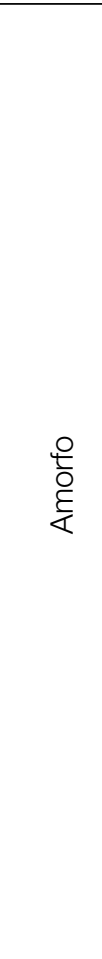 } & $\begin{array}{l}\text { MOA } \\
\text { Material orgânico de fitoplâncton } \\
\text { ou bactéria derivado de ataque } \\
\text { microbiológico }\end{array}$ & $\begin{array}{l}\text { Material não estruturado e com formato variado; cores amarela- } \\
\text { laranja-vermelha, laranja-marrom e cinza; algumas vezes com } \\
\text { inclusões de palinomorfos, fitoclastos, pirita etc; pode exibir } \\
\text { coloração de fluorescência fraca a intensa e ser não fluorescente }\end{array}$ \\
\hline & $\begin{array}{l}\text { Resina } \\
\text { Derivado de vegetais superiores de } \\
\text { florestas tropicais e subtropicais }\end{array}$ & $\begin{array}{l}\text { Partícula não estruturada, hialina, usualmente arredondada, } \\
\text { homogênea, com intensa coloração de fluorescência }\end{array}$ \\
\hline & $\begin{array}{l}\text { MOA de produtos de tecidos vegetais } \\
\text { Fitoclasto Pseudoamorfo/Amorfizado }\end{array}$ & $\begin{array}{l}\text { Contorno difuso; pode ser marrom-claro a marrom-escuro. } \\
\text { Mostra feições de MOA sensu usual e padrão flat. Geralmente } \\
\text { sem inclusões e pode apresentar fraca a intensa coloração de } \\
\text { fluorescência (frequentemente laranja) }\end{array}$ \\
\hline & $\begin{array}{l}\text { MOA bacteriana } \\
\text { Mucilagem } \\
\text { Substância Polimérica Extracelular - EPS }\end{array}$ & $\begin{array}{l}\text { Material não estruturado e contorno difuso; cores amarela-pálida, } \\
\text { amarela, laranja e cinza; algumas vezes inclusões de pirita. } \\
\text { Apresenta aspecto tênue, espessura muito fina ("pelicular", sensu } \\
\text { Combaz, 1980) com impressões de "crateras" pela dissolução de } \\
\text { minerais carbonáticos, após o processo de acidificação. Típica de } \\
\text { níveis carbonáticos, nos quais a principal fonte de matéria orgânica } \\
\text { é um produto rico em lipídios, oriundo da atividade de bactérias } \\
\text { fotossintetizantes, e não devido ao retrabalhamento microbiológico } \\
\text { de outra biomassa. Exibe fluorescência fraca a forte, e em intervalos } \\
\text { dolomitizados geralmente está sem fluorescência }\end{array}$ \\
\hline & $\begin{array}{l}\text { Esteiras Microbiais } \\
\text { MOA derivada da produtividade primária } \\
\text { de bactérias (fotossíntese) }\end{array}$ & $\begin{array}{l}\text { Consiste predominantemente do maternal lamalginita quando observado } \\
\text { em luz refletida. As partículas geralmente têm a forma uniforme com } \\
\text { contornos angulares e retos após o processo de isolamento da matéria } \\
\text { orgânica. Exibe intensa coloração de fluorescência }\end{array}$ \\
\hline
\end{tabular}

MOA: matéria orgânica amorfa.

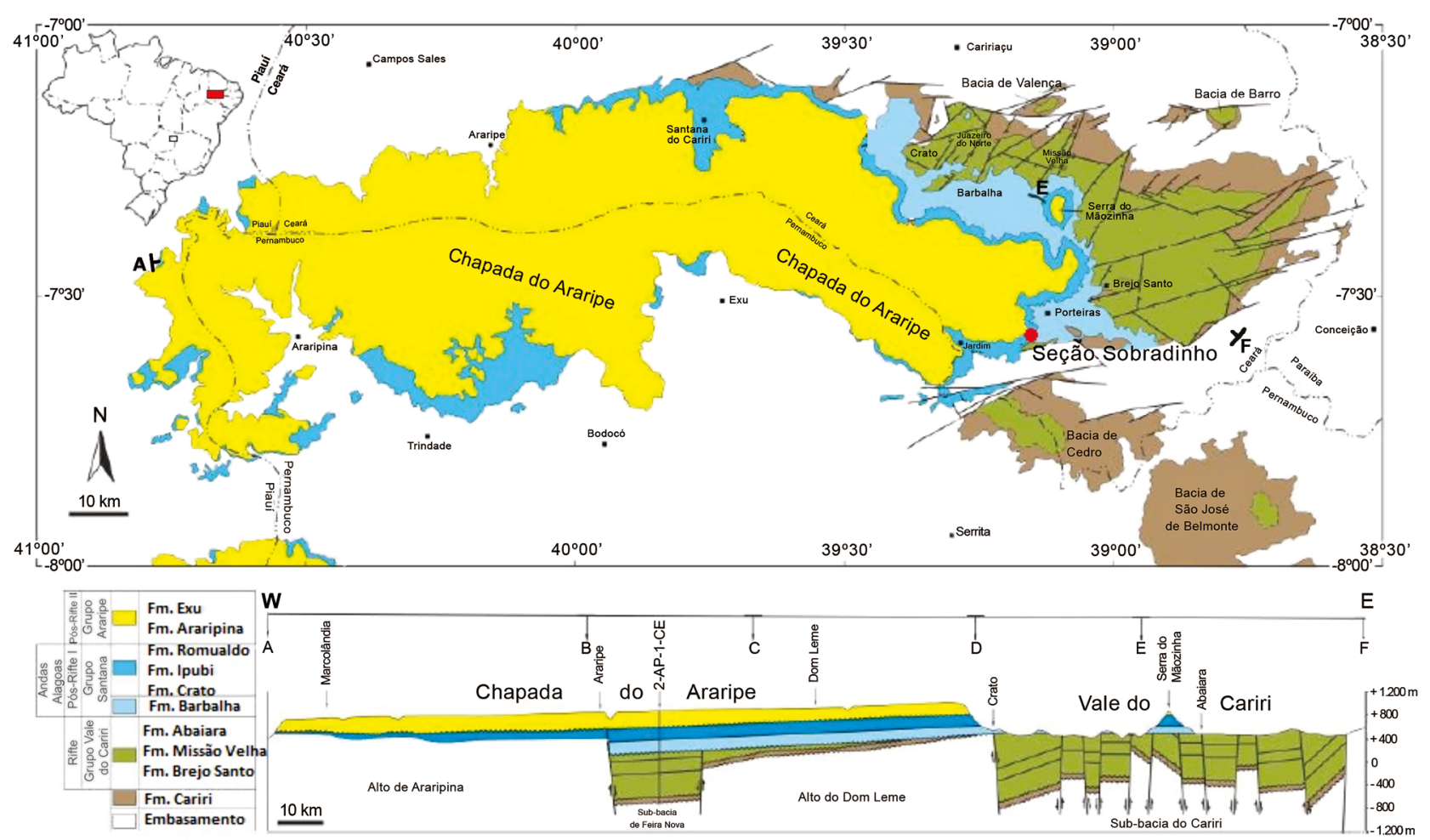

Fm.: Formação. Fonte: modificado de Assine (2007).

Figura 1. Mapa geológico da Bacia do Araripe e localização da Seção Sobradinho. 
antigas do embasamento pré-cambriano, influenciando a forma e a estruturação das bacias interiores do nordeste.

\section{Estratigrafia}

O arcabouço estratigráfico da Bacia do Araripe é constituído por megassequências geradas em regimes tectônicos distintos, o que a configura como bacia de evolução poligenética (Assine, 1990, 1992; Ponte e Appi, 1990; Ponte e Ponte Filho, 1996). As diferentes sequências foram formadas em cenários paleogeográficos diferentes, integrando o contexto da evolução geológica regional das bacias do nordeste do Brasil (Assine, 1994).

As unidades estratigráficas das megassequências pré-rifte e rifte (Assine, 2007) afloram somente na porção leste da bacia, numa área topograficamente deprimida, conhecida como Vale do Cariri, onde os estratos se encontram movimentados por falhas associadas aos horstes e grabens da sub-bacia do Cariri. As unidades das megassequências pós-rifte I e pós-rifte II (Assine, 2007) afloram nas escarpas e sopé da Chapada do Araripe (Figura 1).

A megassequência pós-rifte I, cronoestratigraficamente, pertence ao Andar Alagoas (Aptiano superior/Albiano inferior), e é composta, da base para o topo, pelas formações Barbalha, Crato, Ipubi e Romualdo, constituindo, assim, o Grupo Santana, de acordo com Neumann e Assine (2015). Segundo Assine et al. (2016), duas desconformidades importantes foram identificadas na bacia dentro da sucessão estratigráfica do Andar Alagoas. A primeira foi identificada no topo das Camadas Batateira, cujos folhelhos cinza-escuros a pretos são sobrepostos em contato erosivo por ortoconglomerados polimíticos. A segunda foi identificada no topo da Formação Ipubi, definida pelo contato irregular e erosivo de arenitos e conglomerados da porção inferior da Formação Romualdo por sobre camadas de gipsita e de folhelhos pretos a cinza-escuros da Formação Ipubi. Essas duas desconformidades internas permitiram subdividir o Andar Alagoas em três sequências deposicionais.

A Sequência Deposicional 1 corresponde à metade inferior da Formação Barbalha, essencialmente siliciclástica, com predomínio de fácies de arenitos finos a muito grossos. Os folhelhos das Camadas Batateira estão presentes na parte superior da sequência. Os folhelhos são cinza-escuros a pretos, calcíferos, sendo comum a presença de ostracodes, conchostráceos, restos de peixes e fragmentos vegetais carbonificados. A associação vertical de fácies é típica de tratos de sistemas transgressivos, materializado por fácies de canais fluviais, que gradativamente perdem energia e são recobertos por fácies pelíticas lacustres.

A base da Sequência Deposicional 2 é marcada pela presença de delgadas e descontínuas camadas de conglomerado, que lateralmente passam para arenitos grossos, em contato erosivo sobre os folhelhos das Camadas Batateira.
A deposição de calcários laminados consolida a implantação de sistemas lacustres na bacia. A base da primeira camada de calcário é definida como contato entre as formações Barbalha e Crato. Segundo Neumann (1999), os calcários laminados são essencialmente lacustres, com rico conteúdo fossilífero (Mabesoone e Tinoco, 1973). A existência de pseudomorfos de halita nos calcários laminados evidencia que a bacia experimentou condições de crescente aridez (Martill et al., 2007). Corpos descontínuos de gipsita associados a folhelhos verdes e/ou pretos (pirobetuminosos) ocorrem sobre a seção mista carbonático-siliciclástica da Formação Crato. Os evaporitos e as fácies associadas compõem seção sedimentar de até $30 \mathrm{~m}$ de espessura, litoestratigraficamente denominada Formação Ipubi. No entanto, em grande parte da bacia, os evaporitos nem sempre estão presentes.

A Sequência Deposicional 3 corresponde integralmente à Formação Romualdo, que é caracterizada por ampla gama de litologias (conglomerados estratificados, arenitos finos a grossos, calcários laminados, margas, folhelhos, calcários coquinoides e coquinas). Essa formação é conhecida internacionalmente pelo seu rico conteúdo fossilífero, especialmente peixes encontrados em concreções fossilíferas (Maisey, 1991; Kellner, 2002). Os arenitos costeiros da porção inferior da Formação Romualdo tornam-se mais grossos em direção às porções mais proximais da bacia, onde a descontinuidade é marcada por contato erosivo sobre a associação de fácies evaporítica da Formação Ipubi. Nas porções mais distais da bacia, situadas a leste, a descontinuidade da base da sequência é marcada por brusca mudança de fácies, de calcários laminados da Formação Crato para arenitos da Formação Romualdo, muitas vezes sem a presença da seção evaporítica da Formação Ipubi.

A assembleia de microfósseis da Formação Romualdo apresenta grande diversidade, com grãos de pólen, esporos e ostracodes. Dinocistos (Arai e Coimbra, 1990; Coimbra et al., 2002) e foraminíferos (Dias-Brito et al., 2015) indicam ambientes deposicionais com influência marinha. Destaca-se a existência de intervalos de folhelhos cinza-escuros a pretos, ricos em matéria orgânica e com espessura de até cinco metros, caracterizados pela presença de concreções carbonáticas fossilíferas, portadores de rica paleoictiofauna considerada marinha (Silva Santos e Valença, 1968). A excelente preservação dos peixes nas concreções indica que as águas eram muito calmas e que a mortandade em massa se deveu a mudanças drásticas da salinidade ou da temperatura nas águas superficiais (Martill, 1988; Martill et al., 2008). O reconhecimento de uma superfície de máxima inundação marinha no final da megassequência (Formação Romualdo) permitiu a caracterização de um ciclo transgressivo-regressivo. Fácies fluviais do Grupo Araripe sobrepõem em discordância erosiva regional os estratos do Grupo Santana, marcando o topo do Andar Alagoas na Bacia do Araripe. 


\section{METODOLOGIA}

\section{Materiais}

No presente trabalho, foi utilizado um total de 58 amostras agrupadas em 5 litofácies distintas (folhelho preto, calcário laminado, arenito maciço, coquina e barras arenosas). As amostras são representadas principalmente por folhelho preto, betuminoso, rico em matéria orgânica (47 amostras). Como citado anteriormente, para referência do controle estratigráfico das amostras, foi usada a Seção Colunar Sobradinho, correspondente à ilustração do registro litoestratigráfico da Formação Romualdo na porção leste da Bacia do Araripe, na qual está representado o intervalo amostrado (Figura 2).

\section{Métodos}

\section{Preparação das amostras}

A preparação foi realizada no Laboratório de Preparação de Microfósseis, Setor de Paleontologia e Estratigrafia (Departamento de Geologia - DEGL/Instituto de Geociências IGEO/UFRJ). Inicialmente, o procedimento analítico teve como objetivo o isolamento da fração particulada da matéria orgânica sedimentar. Para a análise de palinofácies, foram aplicados os métodos não oxidativos de maceração ácida, descritos por Tyson (1995), Oliveira et al. (2006) e Mendonça Filho et al. (2010a, 2011), os quais consistem na utilização de ácido clorídrico $(\mathrm{HCl})$ e fluorídrico $(\mathrm{HF})$ para a eliminação da fração mineral. Posteriormente, foi utilizado cloreto de zinco $\left(\mathrm{ZnCl}_{2}\right)$ com o intuito de separar por flotação a fração orgânica da fração inorgânica residual. A fração recuperada de querogênio concentrado foi adicionada em lamínulas de vidro para montagem em lâminas de vidro para análise microscópica. Para a análise de Carbono Orgânico Total (COT) e teor em Enxofre Total (St), as amostras foram pulverizadas e acidificadas com $\mathrm{HCl}$ para eliminação da fração carbonática mineral.

\section{Análise de palinofácies}

De acordo com Mendonça Filho et al. (2012), a análise das associações palinofaciológicas tem como objetivo a integração de todos os aspectos do querogênio, tais como: identificação dos componentes palinológicos individuais (fitoclastos, palinomorfos e matéria orgânica amorfa); classificação dos grupos e subgrupos do querogênio; e determinação das proporções relativas, atentando particularmente ao seu tamanho, forma e estado de preservação. Para este estudo, foi realizado um exame qualitativo (identificação das partículas) e quantitativo (contagem de 300 a 400 partículas) em lâminas organopalinológicas, utilizando-se técnicas de microscopia em luz branca transmitida e modo fluorescência.
A identificação dos componentes do querogênio obedeceu à classificação geral proposta por Tyson (1993, 1995), Mendonça Filho (1999) e Mendonça Filho et al. (2010a, 2011, 2012). A contagem na análise de palinofácies foi realizada com objetiva de $20 x$, utilizando-se ocular com retículo graduado, sendo registradas apenas as partículas sob os retículos (horizontal e vertical). Em conjunto com essa contagem, foi realizada uma contagem associada dos palinomorfos, contabilizando-se todos os componentes que caíram no campo visual.

\section{Análise de Carbono Orgânico Total e teor em Enxofre Total}

As determinações do COT e do teor em St foram realizadas utilizando-se aparelho SC-144DR da LECO, um instrumento de quantificação simultânea de carbono $(C)$ e enxofre $(S)$, composto por forno e detector de infravermelho. O método adotado foi o ASTM D-4239 (American Society for Testing and Materials) (ASTM, 2008).

\section{Tratamento estatístico dos dados}

Os dados obtidos a partir das análises quantitativas dos componentes organopalinológicos foram recalculados para valores percentuais relativos aos grupos e subgrupos da matéria orgânica particulada e, posteriormente, submetidos a análises de agrupamento modo- $Q$ e modo- $R$, por meio do programa STATISTICA 7.0 (Copyright 1984-97, StatSoft, Inc.), com o objetivo de reconhecer o grau de similaridade entre os grupos e subgrupos da matéria orgânica.

\section{RESULTADOS}

\section{Palinofácies}

Descrição dos componentes orgânicos particulados

\section{Grupo Fitoclasto}

Os fitoclastos opacos ocorrem preferencialmente como fragmentos irregulares ou alongados, exibindo contornos subangulares a angulares, subarredondados e corroídos (Figuras 3A a 3H). Partículas degradadas são muito comuns dentre os fitoclastos não opacos. Os fitoclastos não opacos não bioestruturados (Figuras 3I e 3J) ocorrem como partículas degradadas e não degradadas. Os fitoclastos não opacos bioestruturados, por sua vez, ocorrem preferencialmente como partículas degradadas, principalmente em relação aos perfurados (Figuras 3K e 3L) e estriados (Figuras 3M e $3 \mathrm{~N}$ ); os fitoclastos bandados (Figuras $3 \mathrm{O}$ e $3 \mathrm{P}$ ) e listrados (Figuras 3Q e 3R) são os mais bem preservados. Os fitoclastos 
não opacos bem preservados exibem fluorescência laranja a amarela (Figura 3R). As cutículas geralmente ocorrem como fragmentos que apresentam estruturação interna bem marcada, bem preservados e de coloração amarela-pálida a marrom-clara sob luz branca transmitida; exibem fluorescência com intensidade moderada a forte. Por vezes,

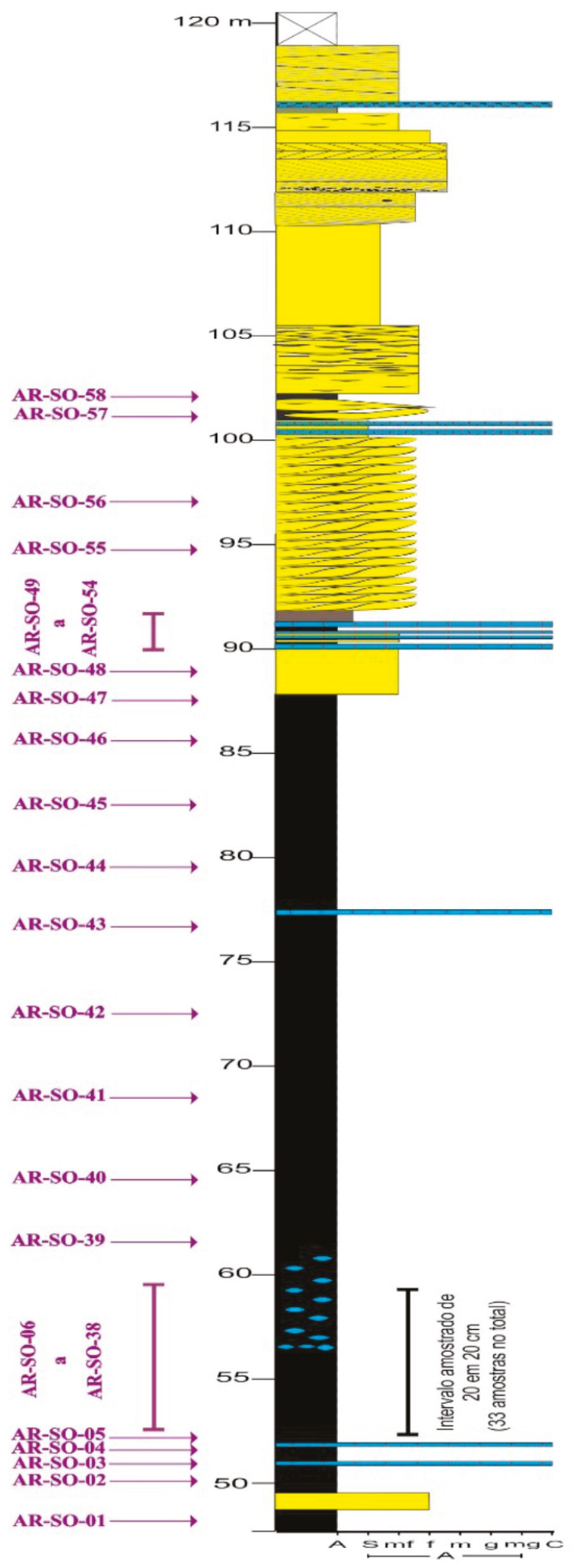

\section{Litologia}

एalcário

$\square$ Arenito

$\square$ Lamito marrom

$\square$ Folhelho cinza

Folhelho preto

$\triangle$ Encoberto

\section{Simbologia}

Estratificaçãa cruzada tangencial na base

आmm: Estratificação cruzada planar

C. Barras amalgamadas

... Clastos de argila

- Concreções e nódulos carbonáticos

\section{Acamamento}

- Flaser

$3=2$ Ondulado

AR-Araripe

SO-Sobradinho

Figura 2. Seção Colunar Sobradinho (Formação Romualdo), com destaque para o posicionamento litoestratigráfico das amostras. 
surgem cutículas com estômatos (Figuras $3 \mathrm{~S}$ e 3T); também é comum a ocorrência de cutículas com elevado grau de amorfização (Figuras $3 \mathrm{U}$ e $3 \mathrm{~V}$ ). As membranas são bem preservadas, mostrando fluorescência intensa; sob luz branca transmitida possuem aspecto de uma película transparente (Figuras 3W e 3X).

\section{Grupo Palinomorfo}

Os esporomorfos ocorrem geralmente bem preservados e apresentam assembleias com elevada diversidade de gêneros e espécies. A principal ocorrência para os esporos (Figuras 4A a 4F) é representada pelos gêneros Cicatricosisporites, Cyathidites, Deltoidospora e Leptolepidites, e dentre os grãos de pólen (Figuras $4 \mathrm{G} \mathrm{a} 4 \mathrm{~L}$ ) as principais ocorrências são as dos gêneros Classopollis, Araucariacites, Gnetaceaepollenites, Inaperturopollenites, Eucommiidites e Afropollis. Outra ocorrência que merece destaque é a do grão de pólen Sergipea variverrucata, em razão do seu importante significado cronoestratigráfico. Tétrades e aglomerados de esporomorfos são comuns. As algas Chlorococcales (Figuras 4M a 4R), principal representante do microplâncton de água doce, ocorrem preferencialmente como componentes degradados, exibindo uma fluorescência de fraca intensidade (Pediastrum e Scenedesmus), com exceção do gênero Botryococcus, que exibe fluorescência de intensidade muito forte (amarela). Os dinoflagelados (Figuras 4S a 4V) apresentam-se bem preservados, com intensidade de fluorescência moderada a forte, sendo transparentes sob luz branca. Os gêneros identificados foram Subtilisphaera e Spiniferites. Os palinoforaminíferos (Figuras 4W e 4X) que, em sua maioria, ocorrem como componentes degradados, com morfologia em espiral e coloração marrom-escura - sob luz branca transmitida - , não apresentam fluorescência.
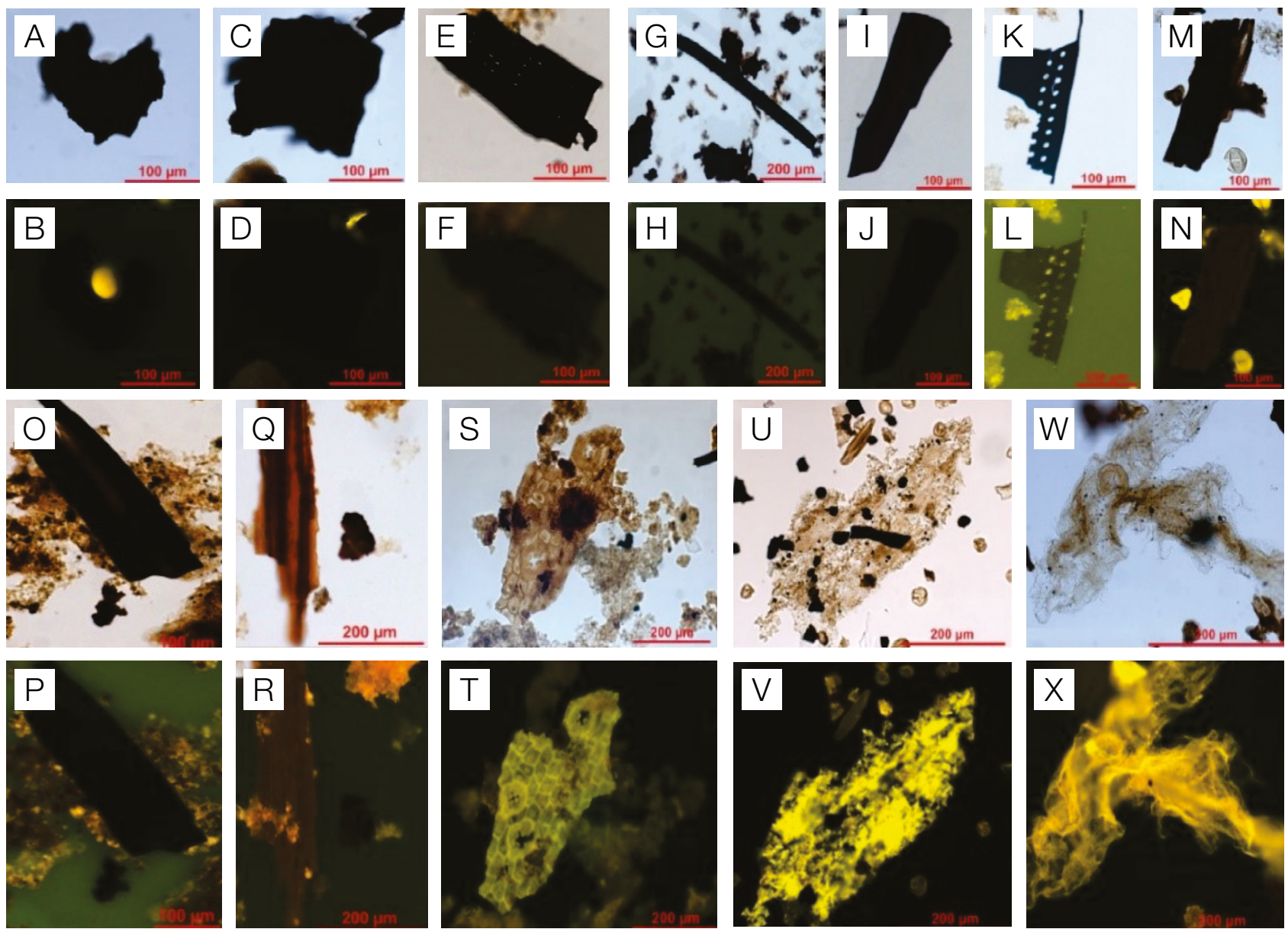

Figura 3. Grupo Fitoclasto. (A-B) fitoclasto opaco corroído; (C-D) fitoclasto opaco equidimensional; (E-F) fitoclasto opaco com perfurações; (G-H) fitoclasto opaco alongado; (I-J) fitoclasto não opaco não bioestruturado; (K-L) fitoclasto não opaco bioestruturado perfurado; $(\mathrm{M}-\mathrm{N})$ fitoclasto não opaco bioestruturado estriado; (O-P) fitoclasto não opaco bioestruturado bandado; (Q-R) fitoclasto não opaco bioestruturado listrado; (S-T) cutícula com estômatos; (U-V) cutícula amorfizada; (W-X) membrana (Fotomicrografias A, C, E, G, I, K, M, O, Q, S, U e W - modo luz branca transmitida; Fotomicrografias $B, D, F, H, J, L, N, P, R, T, V$ e X - modo fluorescência). 
Verificou-se ainda a ocorrência de componentes de idade Paleozoica, representados por esporos trilete indeterminados, apresentando elevado grau de degradação, também prasinófitas do gênero Maranhites, quitinozoário e fragmentos de Spongiophyton. Os esporos trilete indeterminados, prasinófitas e Spongiophyton possuem fluorescência fraca, geralmente de cor laranja. Os quitinozoários não possuem fluorescência.

\section{Grupo Amorfo}

A MOA ocorre de três formas distintas, as quais foram denominadas MOA fina, MOA espessa e MOA estratificada. A primeira (Figuras 5A a 5F) exibe coloração bege-pálida a marrom-clara, sob luz branca. Apresenta aspecto granular, fino (lenticular), quase transparente, de contornos irregulares a retilíneos. Mostra fluorescência moderada a forte, de cor laranja a amarela. Inclusões de pirita, grânulos fluorescentes, esporomorfos e diminutos fragmentos de fitoclastos são comuns.

A segunda (Figuras 5G a 5L) apresenta coloração castanha a marrom-escura sob luz branca transmitida.
De aspecto granular, espesso, com contornos irregulares a retilíneos, por vezes formando arestas. Apresenta fluorescência de cor laranja a amarela, e também inclusões de pirita, esporomorfos, fragmentos de fitoclastos e grânulos fluorescentes. Muitas partículas apresentam marcas de impressão de tecidos cuticulares e de fitoclastos (Figuras 5I e 5J). Nas amostras em que ocorre abundância de dinocistos, essas partículas mostram íntima associação com tais componentes. A ocorrência de "crateras" também é um aspecto comum.

A terceira forma de MOA (Figuras $5 \mathrm{M}$ e $5 \mathrm{~N}$ ) possui coloração marrom-escura sob luz branca, mostrando padrão interno estratificado, como que evidenciando a sobreposição de finas camadas de material amorfo. Apresenta contornos irregulares, com fluorescência laranja a amarela; possui inclusões de pirita e de grânulos fluorescentes. Algumas partículas apresentam diminutas crateras, provavelmente provenientes da dissolução de grãos minerais (carbonatos).

As resinas (Figuras $5 \mathrm{O}$ e 5P) apresentam, preferencialmente, formas circulares a subcirculares, e também formas prismáticas, demonstrando textura hialina característica, com intensidade de fluorescência muito forte.
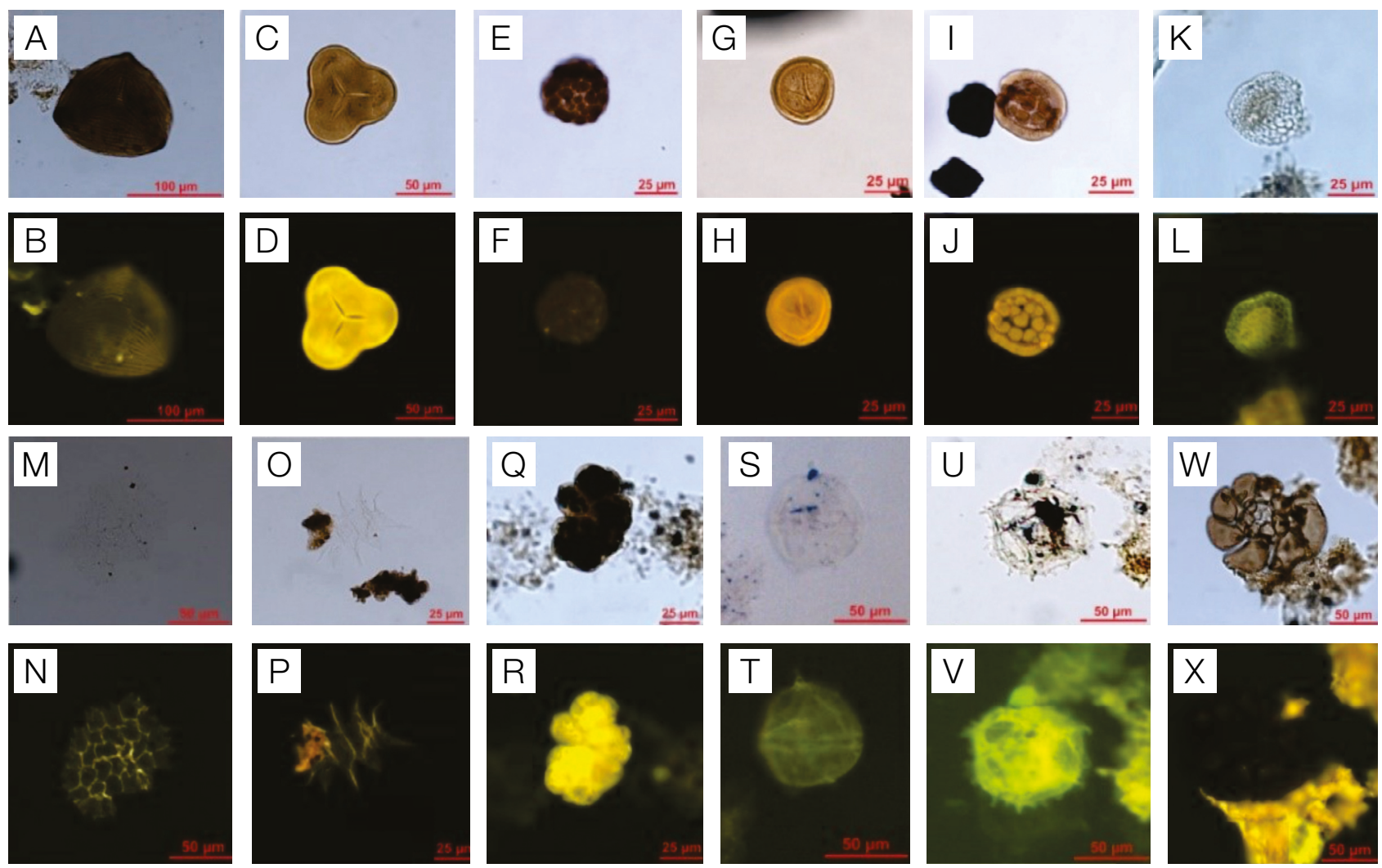

Figura 4. Grupo Palinomorfo. (A-B) Cicatricosisporites; (C-D) Cyathidites; (E-F) Leptolepidites; (G-H) Classopollis; (I-J) Sergipea variverrucata; (K-L) Afropollis; (M-N) Pediastrum; (O-P) Scenedesmus; (Q-R) Botryococcus; (S-T) Subtilisphaera; (U-V) Spiniferites; (W-X) palinoforaminífero (Fotomicrografias A, C, E, G, I, K, M, O, Q, S, U e W - modo luz branca transmitida; Fotomicrografias $\mathrm{B}, \mathrm{D}, \mathrm{F}, \mathrm{H}, \mathrm{J}, \mathrm{L}, \mathrm{N}, \mathrm{P}, \mathrm{R}, \mathrm{T}, \mathrm{V}$ e X - modo fluorescência). 


\section{Contagem dos componentes orgânicos particulados}

Os resultados da contagem dos principais subgrupos de componentes orgânicos particulados, em relação ao total da matéria orgânica, estão expostos nas Tabelas 4 e 5. A Figura 6 ilustra a distribuição dos principais subgrupos ao longo do perfil analisado. De acordo com os dados apresentados, verifica-se que para o Grupo Amorfo, a MOA fina é o subgrupo dominante, com a MOA espessa também apresentando ocorrência expressiva. A MOA estratificada e as resinas ocorrem com concentrações bem mais reduzidas.

Os componentes não opacos não bioestruturados são dominantes em relação aos demais no Grupo Fitoclasto, com distribuição expressiva ao longo do topo e na base do perfil analisado. Esse mesmo padrão de distribuição é compartilhado pelos demais componentes lenhosos (fitoclastos opacos, fitoclastos não opacos bioestruturados, cutículas e membranas). Os fitoclastos não opacos bioestruturados são representados, em sua maioria, por partículas estriadas e listradas; já os fitoclastos opacos são constituídos principalmente por partículas corroídas e equidimensionais.

Da mesma forma que os fitoclastos, os esporomorfos apresentam ocorrência bem mais expressiva na base e no topo do perfil, sendo representados principalmente por grãos de pólen de morfologia simples, pertencentes ao gênero Classopollis. Dentre o subgrupo do microplâncton de água
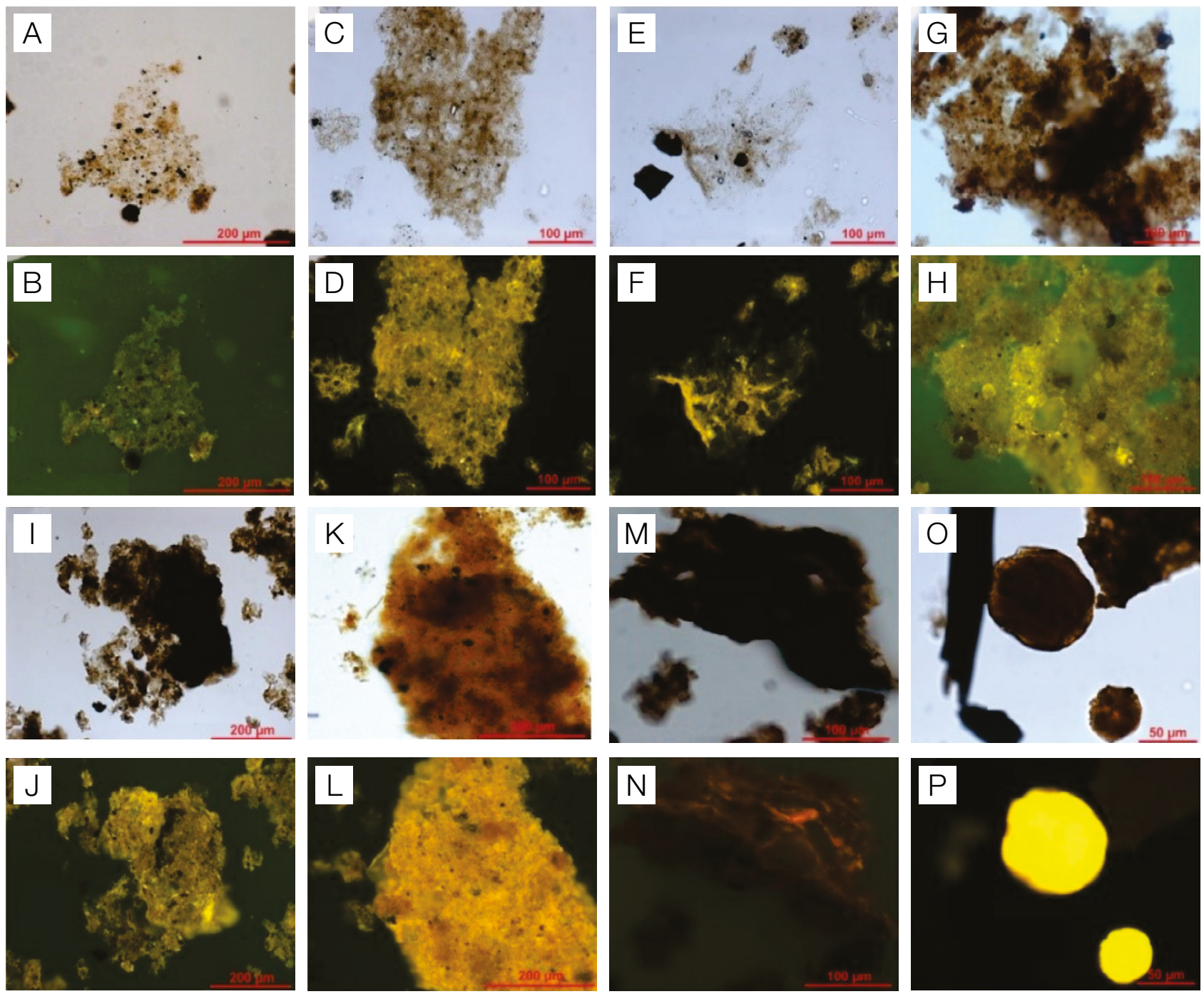

Figura 5. Grupo Amorfo. (A-D) matéria orgânica amorfa fina de contornos regulares; (E-F) matéria orgânica amorfa fina de aspecto filamentoso; $(\mathrm{G}-\mathrm{H})$ matéria orgânica amorfa espessa com crateras; (I-J) matéria orgânica amorfa espessa associada com fitoclasto amorfizado; (K-L) matéria orgânica amorfa espessa com inclusão de grânulos fluorescentes; (M-N) matéria orgânica amorfa estratificada com crateras de dissolução; (O-P) resina (Fotomicrografias A, C, E, G, I, K, M e O - modo luz branca transmitida; Fotomicrografias B, D, F, H, J, L, N e P - modo fluorescência). 
doce, o gênero Pediastrum ocorre em maiores concentrações, seguido por Scenedesmus e Botryococcus, ambos com maior representatividade na porção superior do perfil. O subgrupo dos componentes marinhos é representado principalmente por dinocistos, pertencentes aos gêneros Subtilisphaera (majoritariamente dominante) e Spiniferites, com palinoforaminíferos ocorrendo de modo restrito e em baixas concentrações.

O diagrama ternário MOA-Fitoclasto-Palinomorfo (MFP) (Figura 7) evidencia a ocorrência de duas assembleias distintas da matéria orgânica: uma dominada pelo Grupo Amorfo; e a outra com predomínio do Grupo Fitoclasto. A assembleia com dominância do Grupo Amorfo ocorre predominantemente na litofácies folhelho negro e em outras duas amostras: uma da litofácies calcário laminado (AR-SO-05), na base do perfil; e outra pertencente à litofácies coquina (AR-SO-49), no topo do perfil. Já a assembleia dominada pelo Grupo Fitoclasto ocorre distribuída por todas as litofácies consideradas, alocada preferencialmente na base e no topo do perfil.

Tabela 4. Valores percentuais dos grupos e subgrupos da matéria orgânica particulada em relação ao total de matéria orgânica (amostras AR-SO-01 a AR-SO-29).

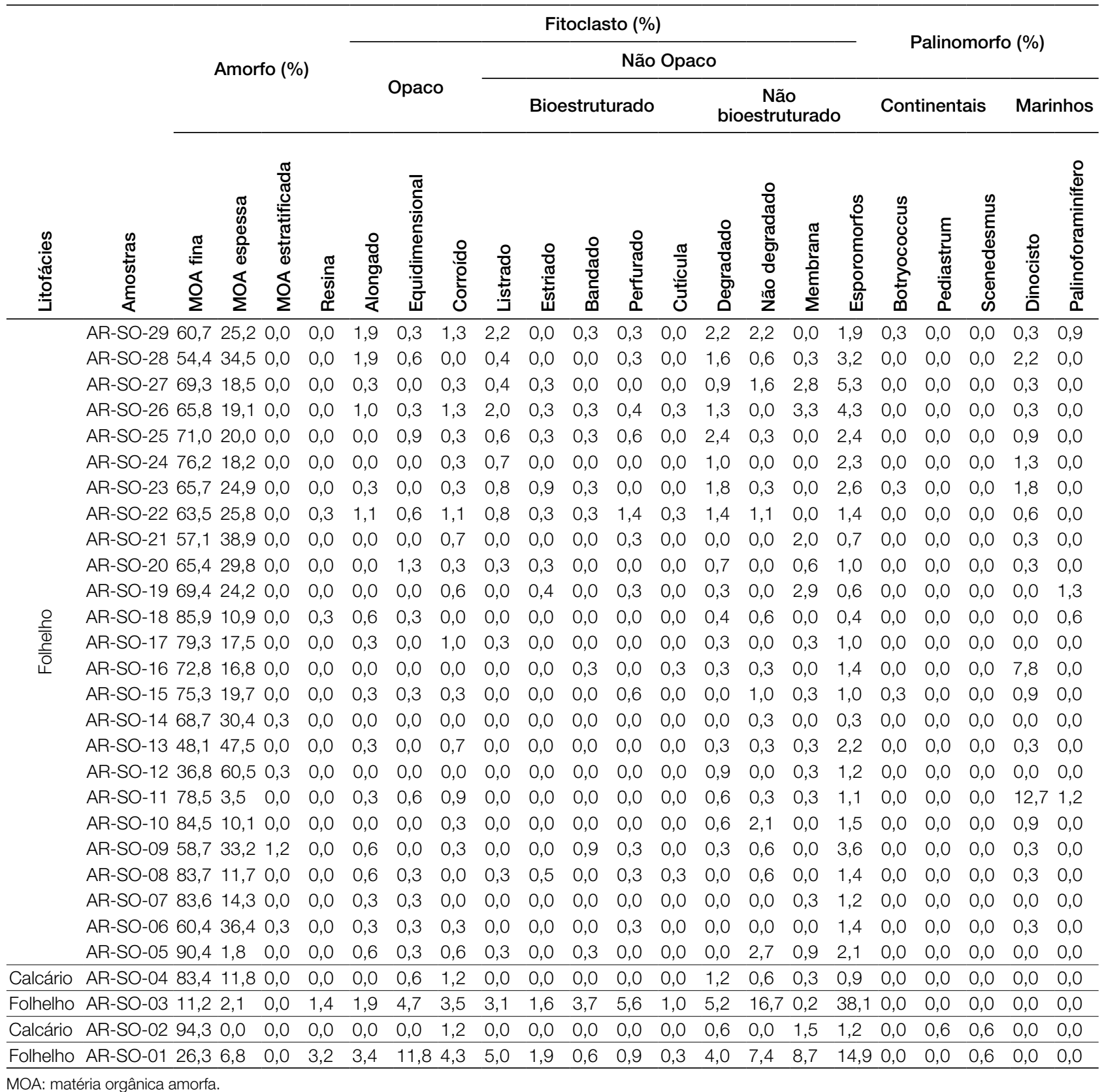


Os componentes de idade Paleozoica (esporos trilete indeterminados, prasinófitas, gênero Maranhites, Spongiophyton, quitinozoários), oriundos de retrabalhamento, reconhecidos principalmente pela coloração de fluorescência, ocorrem em determinadas amostras da base (AR-SO-01, AR-SO-02, AR-SO-03), da porção mediana (AR-SO-22) e do topo do perfil (AR-SO-37, AR-SO-42, AR-SO-44, AR-SO-46, AR-SO47). Por apresentarem idade incompatível com a seção litológica estudada - a qual pertence ao Cretáceo - , esses componentes não foram inseridos na contagem da palinofácies.

\section{Tratamento estatístico dos dados}

Os parâmetros utilizados para determinação do grau de similaridade entre as amostras foram os valores de abundância relativa dos componentes orgânicos particulados, dentre os quais foram selecionados os seguintes: fitoclasto opaco, fitoclasto não opaco não bioestruturado, fitoclasto não opaco bioestruturado, cutícula, membrana, esporomorfos, Pediastrum, Scenedesmus, Botryococcus, dinocisto, MOA fina, MOA espessa, MOA estratificada e resina.

Tabela 5. Valores percentuais dos grupos e subgrupos da matéria orgânica particulada em relação ao total de matéria orgânica (amostras AR-SO-30 a AR-SO-58).

\begin{tabular}{|c|c|c|c|c|c|c|c|c|c|c|c|c|c|c|c|c|c|c|c|c|c|c|}
\hline \multirow[b]{4}{*}{ 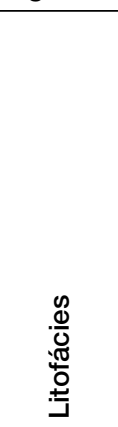 } & \multirow[b]{4}{*}{ 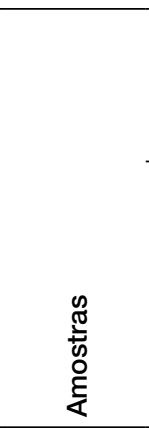 } & \multirow{3}{*}{\multicolumn{4}{|c|}{ Amorfo (\%) }} & \multicolumn{11}{|c|}{ Fitoclasto (\%) } & \multirow{2}{*}{\multicolumn{6}{|c|}{ Palinomorfo (\%) }} \\
\hline & & & & & & \multirow{2}{*}{\multicolumn{4}{|c|}{ Opaco }} & \multicolumn{7}{|c|}{ Não Opaco } & & & & & & \\
\hline & & & & & & & & & & Bioe: & ctru & do & & bic & $\begin{array}{l}\mathrm{N} \tilde{a} \\
\text { stru }\end{array}$ & do & \multicolumn{4}{|c|}{ Continentais } & \multicolumn{2}{|c|}{ Marinhos } \\
\hline & & 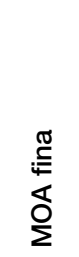 & 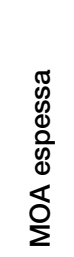 & 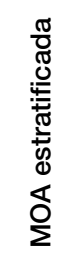 & 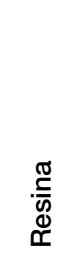 & 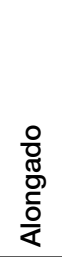 & 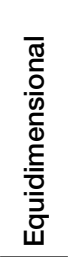 & $\begin{array}{l}\text { 음 } \\
\text { 은 } \\
\text { 임 }\end{array}$ & $\begin{array}{l}\frac{0}{0} \\
\frac{\pi}{5} \\
\frac{0}{3}\end{array}$ & 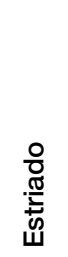 & 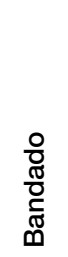 & $\begin{array}{l}\text { 음 } \\
\frac{\pi}{5} \\
\frac{1}{0} \\
0\end{array}$ & 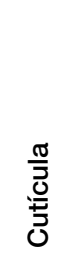 & 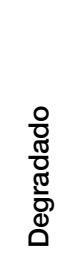 & 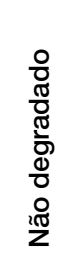 & 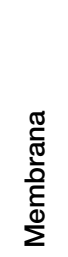 & 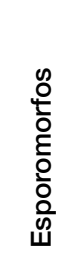 & 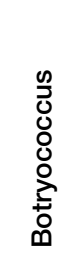 & 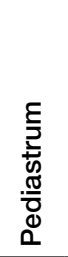 & 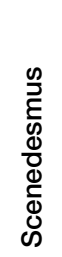 & 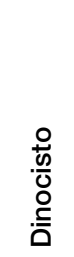 & 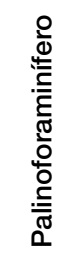 \\
\hline \multirow{4}{*}{ Barras } & AR-SO-58 & 0,0 & 0,0 & 0,0 & 1,2 & 3,7 & 12,1 & 46,7 & 0,6 & 0,0 & 0,3 & 0,3 & 7,0 & 20,9 & 4,2 & 0,6 & 1,2 & 0,0 & 0,9 & 0,3 & 0,0 & 0,0 \\
\hline & AR-SO-57 & 0,0 & 0,0 & 0,0 & 2,7 & 2,1 & 16,8 & 44,5 & 0,3 & 0,3 & 0,6 & 0,7 & 1,2 & 20,7 & 5,5 & 0,6 & 4,0 & 0,0 & 0,0 & 0,0 & 0,0 & 0,0 \\
\hline & AR-SO-56 & 0,0 & 0,0 & 0,0 & 0,0 & 0,6 & 2,9 & 0,0 & 8,3 & 4,5 & 0,0 & 0,0 & 13,1 & 60,3 & 4,2 & 0,0 & 2,9 & 0,0 & 3,2 & 0,0 & 0,0 & 0,0 \\
\hline & AR-SO-55 & 4,3 & 0,0 & 0,0 & 1,2 & 4,9 & 13,5 & 1,8 & 2,5 & 0,0 & 0,9 & 0,9 & 3,7 & 37,8 & 10,4 & 1,5 & 7,1 & 0,0 & 8,9 & 0,6 & 0,0 & 0,0 \\
\hline Coquina & AR-SO-54 & 8,9 & 0,0 & 0,0 & 0,0 & 7,9 & 19,1 & 5,9 & 1,7 & 0,0 & 0,0 & 1,3 & 6,6 & 19,1 & 15,2 & 1,7 & 8,3 & 0,0 & 0,0 & 0,0 & 4,3 & 0,0 \\
\hline Folhelho & AR-SO-53 & 23,6 & 0,0 & 0,0 & 1,4 & 5,4 & 15,5 & 3,7 & 1,0 & 0,7 & 0,0 & 0,7 & 3,7 & 19,3 & 7,4 & 0,0 & 6,4 & 0,0 & 0,0 & 0,0 & 11,1 & 0,0 \\
\hline \multirow{2}{*}{ Coquina } & AR-SC & 20,4 & 0,0 & 0,0 & 2,4 & 6,6 & 11,8 & 2,9 & 1,6 & 0,0 & 0,4 & 0,4 & 5,3 & 12,7 & 10,6 & 0,8 & 6,5 & 0,0 & 0,0 & 0 & 7,6 & 0,0 \\
\hline & AR-SO-51 & 25,5 & 0,8 & 0,0 & 1,6 & 3,0 & 9,0 & 3,0 & 1,6 & 0,9 & 0,8 & 0,5 & 3,8 & 14,9 & 15,8 & 2,2 & 6,0 & 0,0 & 0,0 & 0,0 & 10,3 & 0,3 \\
\hline Folhelho & AR-SO-50 & 41,9 & 2,6 & 0,0 & 1,5 & 2,1 & 9,7 & 2,9 & 1,8 & 0,3 & 0,3 & 0,0 & 1,1 & 10,9 & 15,8 & 1,8 & 5,8 & 0,0 & 0,3 & 0,0 & 1,2 & 0,0 \\
\hline Coquina & AR-SO-49 & 56,3 & 1,4 & 0,0 & 0,3 & 1,6 & 5,7 & 4,6 & 0,8 & 0,5 & 0,0 & 0,3 & 0,3 & 19,0 & 6,5 & 0,5 & 1,4 & 0,0 & 0,0 & 0,0 & 0,0 & 0,8 \\
\hline Arenito & AR-SO-48 & 0,9 & 3,7 & 0,0 & 0,0 & 0,0 & 1,8 & 0,3 & 7,9 & 9,1 & 0,3 & 0,0 & 1,5 & 65,1 & 5,8 & 1,8 & 1,2 & 0,3 & 0,3 & 0,0 & 0,0 & 0,0 \\
\hline \multirow{18}{*}{ Folhelho } & AR-SO-47 & 0,0 & 0,0 & 0,0 & 1,3 & 0,3 & 0,6 & 0,0 & 7,9 & 2,1 & 0,0 & 0,3 & 6,7 & 62,8 & 8,9 & 6,4 & 2,7 & 0,0 & 0,0 & 0,0 & 0,0 & 0,0 \\
\hline & AR-SO-46 & 2,6 & 0,6 & 0,0 & 1,3 & 0,3 & 0,6 & 0,3 & 1,6 & 1,3 & 0,3 & 0,3 & 1,0 & 70,7 & 6,7 & 5,1 & 4,1 & 0,0 & 1,9 & 1,3 & 0,0 & 0,0 \\
\hline & AR-SO-45 & 3,2 & 0,0 & 0,0 & 0,3 & 0,0 & 0,9 & 0,3 & 8,0 & 0,6 & 0,0 & 0,0 & 1,7 & 64,3 & 13,0 & 1,8 & 2,7 & 0,0 & 2,6 & 0,6 & 0,0 & 0,0 \\
\hline & AR-SO-44 & 9,4 & 1,3 & 0,0 & 1,9 & 1,6 & 6,0 & 0,6 & 1,6 & 0,3 & 0,9 & 0,3 & 0,9 & 53,3 & 5,3 & 3,1 & 10,7 & 0,0 & 1,9 & 0,9 & 0,0 & 0,0 \\
\hline & AR-SO-43 & 64,2 & 2,9 & 0,0 & 1,0 & 0,6 & 1,3 & 1,3 & 0,3 & 0,6 & 0,0 & 0,3 & 0,6 & 15,7 & 5,1 & 1,0 & 2,9 & 0,0 & 0,0 & 0,0 & 1,9 & 0,3 \\
\hline & AR-SO-42 & 35,6 & 10,0 & 0,0 & 5,5 & 0,3 & 0,9 & 0,9 & 4,3 & 1,5 & 0,0 & 0,0 & 0,9 & 23,1 & 13,4 & 1,2 & 1,5 & 0,0 & 0,3 & 0,0 & 0,6 & 0,0 \\
\hline & AR-SO-41 & 78,1 & 0,0 & 0,0 & 0,3 & 2,1 & 0,6 & 0,6 & 0,6 & 0,6 & 0,0 & 0,3 & 2,8 & 5,2 & 2,1 & 1,2 & 2,8 & 0,0 & 0,0 & 0,0 & 0,3 & 2,4 \\
\hline & AR-SO-40 & 76,8 & 2,6 & 0,0 & 0,0 & 0,0 & 0,0 & 0,0 & 1,2 & 0,0 & 0,3 & 0,6 & 0,0 & 9,7 & 4,4 & 0,0 & 0,9 & 0,0 & 0,0 & 0,0 & 0,0 & 3,5 \\
\hline & AR-SO-39 & 85,8 & 3,8 & 0,0 & 0,0 & 0,6 & 0,7 & 0,0 & 0,3 & 0,9 & 0,0 & 0,0 & 0,0 & 6,4 & 0,0 & 0,6 & 0,6 & 0,3 & 0,0 & 0,0 & 0,0 & 0,0 \\
\hline & AR-SO-38 & 88,9 & 4,2 & 0,0 & 0,0 & 0,9 & 0,3 & 0,0 & 0,3 & 0,0 & 0,0 & 0,0 & 0,0 & 1,2 & 0,3 & 0,0 & 3,3 & 0,0 & 0,0 & 0,0 & 0,6 & 0,0 \\
\hline & AR-SO-37 & 82,8 & 10,2 & 0,0 & 0,0 & 0,0 & 0,3 & 1,3 & 1,7 & 0,7 & 0,0 & 0,3 & 0,0 & 0,7 & 0,0 & 0,7 & 1,0 & 0,0 & 0,0 & 0,0 & 0,3 & 0,0 \\
\hline & AR-SO-36 & 83,0 & 11,4 & 0,0 & 0,0 & 0,0 & 0,0 & 0,0 & 1,6 & 0,0 & 0,0 & 0,0 & 0,0 & 2,2 & 0,6 & 0,3 & 0,9 & 0,0 & 0,0 & 0,0 & 0,0 & 0,0 \\
\hline & AR-SO-35 & 80,2 & 13,4 & 0,0 & 0,0 & 0,0 & 0,3 & 0,0 & 1,0 & 0,6 & 0,0 & 0,0 & 0,0 & 3,5 & 0,0 & 0,0 & 1,0 & 0,0 & 0,0 & 0,0 & 0,0 & 0,0 \\
\hline & AR-SO-34 & 81,8 & 12,7 & 0,0 & 0,0 & 0,7 & 0,3 & 0,3 & 0,3 & 0,0 & 0,0 & 0,0 & 0,0 & 1,0 & 0,0 & 0,0 & 0,9 & 0,0 & 0,0 & 0,0 & 2,0 & 0,0 \\
\hline & AR-SO-33 & 80,8 & 12,4 & 0,0 & 0,0 & 1,4 & 0,0 & 0,0 & 1,5 & 0,3 & 0,0 & 0,0 & 0,0 & 0,3 & 1,5 & 0,0 & 0,6 & 0,0 & 0,0 & 0,0 & 0,9 & 0,3 \\
\hline & AR-SO-32 & 76,8 & 14,1 & 0,0 & 0,0 & 0,4 & 0,0 & 0,3 & 0,6 & 0,4 & 0,0 & 0,0 & 0,3 & 3,9 & 0,3 & 0,6 & 2,0 & 0,0 & 0,0 & 0,0 & 0,3 & 0,0 \\
\hline & AR-SO-31 & 68,0 & 20,3 & 0,0 & 0,0 & 1,2 & 0,6 & 1,3 & 1,2 & 0,0 & 0,0 & 0,0 & 0,3 & 3,1 & 0,3 & 0,6 & 0,6 & 0,0 & 0,0 & 0,0 & 2,5 & 0,0 \\
\hline & AR-SO-30 & 69,1 & 19,4 & 0,0 & 0,0 & 0,7 & 0,3 & 1,6 & 0,3 & 1,0 & 0,0 & 0,3 & 0,0 & 3,8 & 1,3 & 0,3 & 1,6 & 0,0 & 0,0 & 0,0 & 0,3 & 0,0 \\
\hline
\end{tabular}

MOA: matéria orgânica amorfa. 
A análise de agrupamento modo- $R$ evidenciou claramente a organização dos componentes orgânicos particulados em três associações de palinofácies - A, B e C com base no maior grau de similaridade em relação à sua origem (Figura 8). De acordo com o dendrograma é possível notar que as três associações reúnem os componentes orgânicos com mesma tendência na distribuição, seja em relação ao caráter proximal-distal ou à equivalência hidrodinâmica das partículas.

A associação de palinofácies A é representada pelo total da MOA fina, da MOA espessa e da MOA estratificada e por componentes de origem continental lacustre (Botryococcus). $\mathrm{Na}$ associação de palinofácies B estão reunidos os componentes lenhosos não opacos do Grupo Fitoclasto (fitoclastos bioestruturados e não bioestruturados, cutículas e membranas) e componentes lacustres (Pediastrum e Scenedesmus). $A$ associação de palinofácies $C$ reúne componentes lenhosos (fitoclastos opacos), componentes amorfos de origem vegetal (resinas), componentes continentais terrestres (esporomorfos) e componentes marinhos (dinocistos). Percebe-se nessa última associação que o agrupamento dos componentes está relacionado, possivelmente, ao comportamento hidrodinâmico das partículas, o que permitiu agrupar componentes de origem continental terrestre (esporomorfos) com componentes de origem marinha.

A análise pelo modo- $Q$ revelou a ocorrência de dois agrupamentos (G1 e G2) de similaridade entre as amostras (Figura 9). Essa mesma tendência foi observada na plotagem dos grupos principais da matéria orgânica no diagrama ternário MFP (Figura 7). Os valores percentuais da contagem associada dos palinomorfos também foram submetidos ao agrupamento modo- $Q$, evidenciando a ocorrência de três agrupamentos com características específicas (G1, G2 e G3) (Figura 10). Esses agrupamentos foram plotados estratigraficamente e possibilitaram a identificação de cinco intervalos (intervalos I, II, III, IV e V) para o perfil

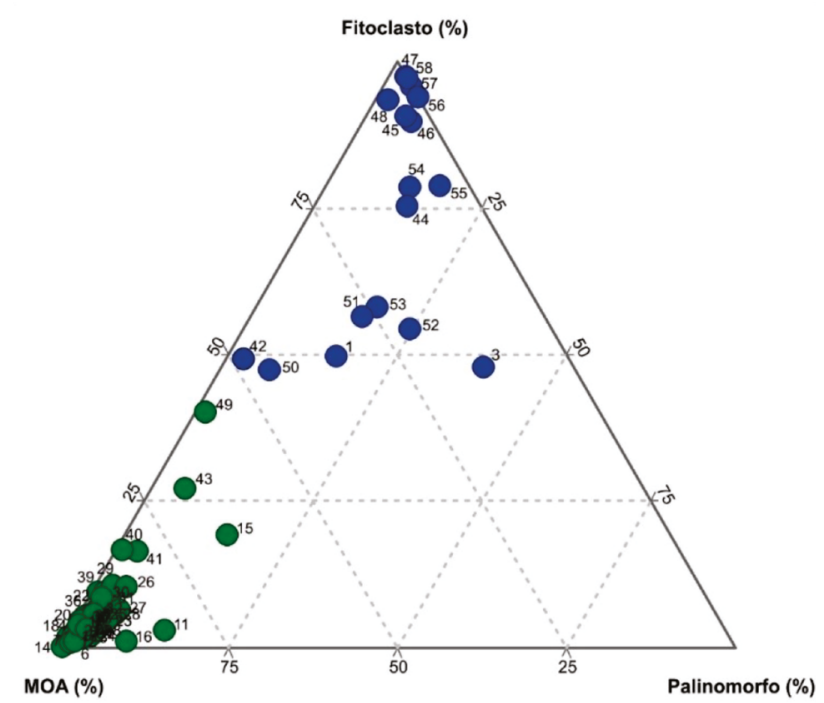

MOA: matéria orgânica amorfa.

Figura 7. Diagrama ternário MOA-Fitoclasto-Palinomorfo. Esferas verdes representam as amostras com dominância do Grupo Amorfo e as esferas azuis representam amostras com predomínio do Grupo Fitoclasto.

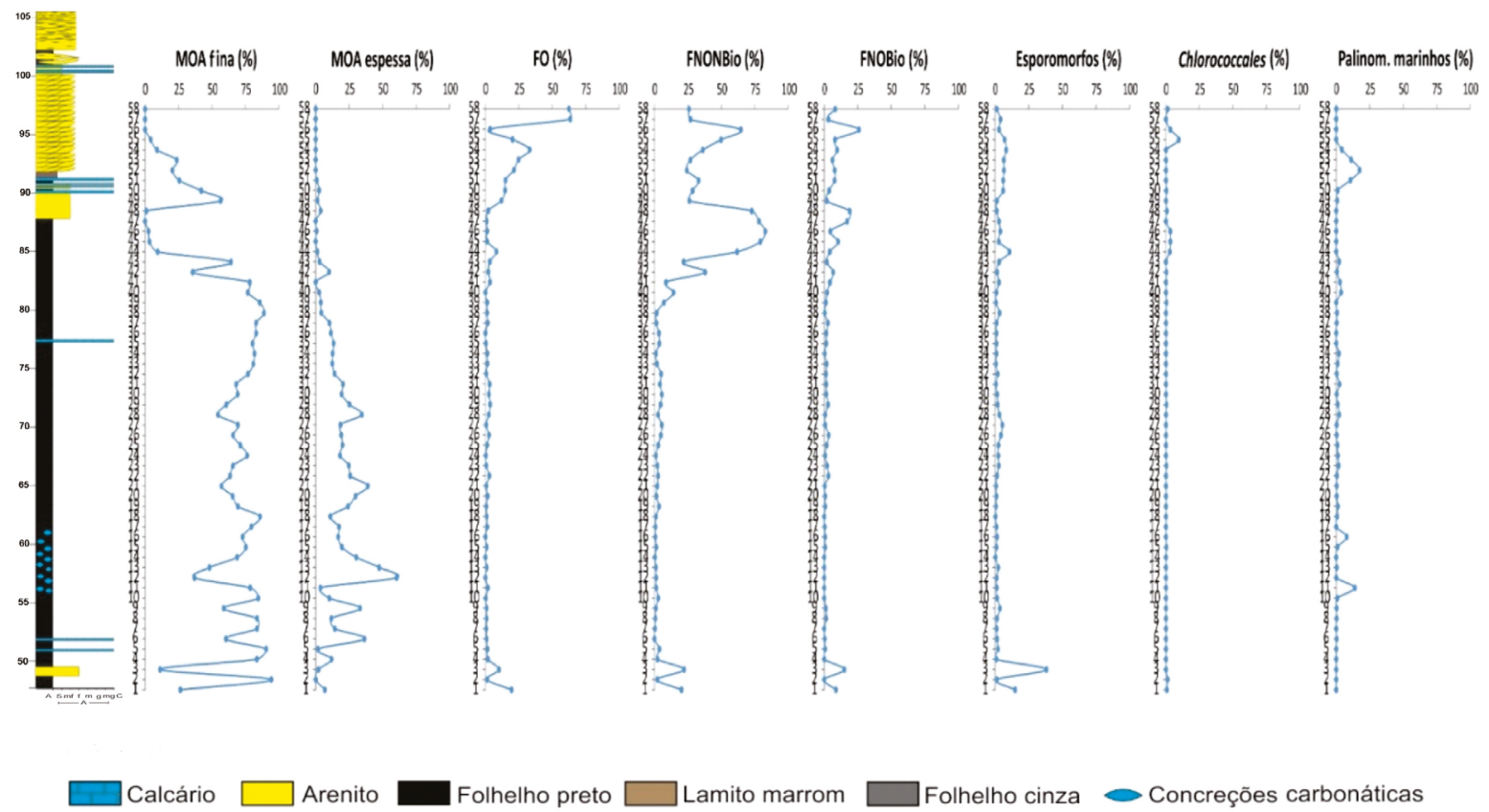

FO: fitoclasto opaco; FNONBio: fitoclasto não opaco não bioestruturado; FNOBio: fitoclasto não opaco bioestruturado.

Figura 6. Distribuição dos principais subgrupos da matéria orgânica particulada ao longo do perfil analisado. 
analisado, separados de acordo com as proporções de seus constituintes orgânicos (Figura 11).

O agrupamento G1 da palinofácies é caracterizado pelas associações de palinofácies $\mathrm{A}$ e $\mathrm{C}$, apresentando a MOA como constituinte dominante, distribuído por toda a porção mediana do perfil analisado. A MOA fina aparece como constituinte mais representativo ( 36,9 a $94,3 \%)$, seguida pela MOA espessa $(0,0$ a $60,5 \%)$ e pela MOA estratificada $(0,0$ a $1,2 \%)$. A resina apresenta valores percentuais entre $0,0 \mathrm{e}$ $0,3 \%$. O fitoclasto não opaco não bioestruturado ocorre com concentrações entre 0,0 e $14,6 \%$, e o fitoclasto não opaco bioestruturado com 0,0 a 3,5\%. Cutículas e membranas apresentam concentrações entre 0,0 e $2,8 \%$ e entre 0,0 e 3,3\%, respectivamente. $O$ fitoclasto opaco possui concentração de 0,0 a $3,5 \%$. Os palinomorfos são representados principalmente por dinocistos $(0,0$ a $12,8 \%)$, seguidos pelos esporomorfos ( 0,3 a 5,3\%), Scenedesmus ( 0,0 a $0,6 \%)$, Pediastrum $(0,0$ a $0,6 \%)$ e Botryococcus $(0,0$ a $0,3 \%)$.

$\mathrm{O}$ agrupamento $\mathrm{G} 2$ da palinofácies é composto principalmente pelas associações de palinofácies B e C, com a associação A ocorrendo de forma restrita. Está alocado na base e por toda a porção superior do perfil, e é caracterizado por dominância do Grupo Fitoclasto. O subgrupo mais representativo é o fitoclasto não opaco não bioestruturado (11,5 a 77,6\%), seguido por fitoclasto opaco $(0,9$ a $63,4 \%$ ), fitoclasto não opaco bioestruturado (1,2 a 17,3\%), cutícula $(0,3$ a $13,1 \%)$ e membrana $(0,0$ a $8,7 \%)$. Os esporomorfos apresentam concentrações elevadas (1,2 a 38,1\%). Botryococcus, Pediastrum e Scenedesmus constituem valores percentuais entre 0,0 e $1,3 \% ; 0,0$ e $8,9 \%$ e entre 0,0 e $1,3 \%$, respectivamente. Os dinocistos ocorrem em concentrações mais elevadas $(0,0$ a $17,6 \%)$ somente em algumas amostras (AR-SO-51, AR-SO-52 e AR-SO-53), localizadas na porção superior. A MOA é constituída pela MOA fina $(0,0$ a $64,4 \%)$ e pela MOA espessa $(0,0$ a $10,0 \%)$. A resina ocorre com concentrações entre 0,0 e $5,5 \%$.

O agrupamento G1 da contagem associada dos palinomorfos é caracterizado por abundância de grãos de pólen (78,4 a $100,0 \%)$, seguidos pelos dinocistos $(0,0$ a $14,6 \%)$, em relação ao total de palinomorfos para esse agrupamento.

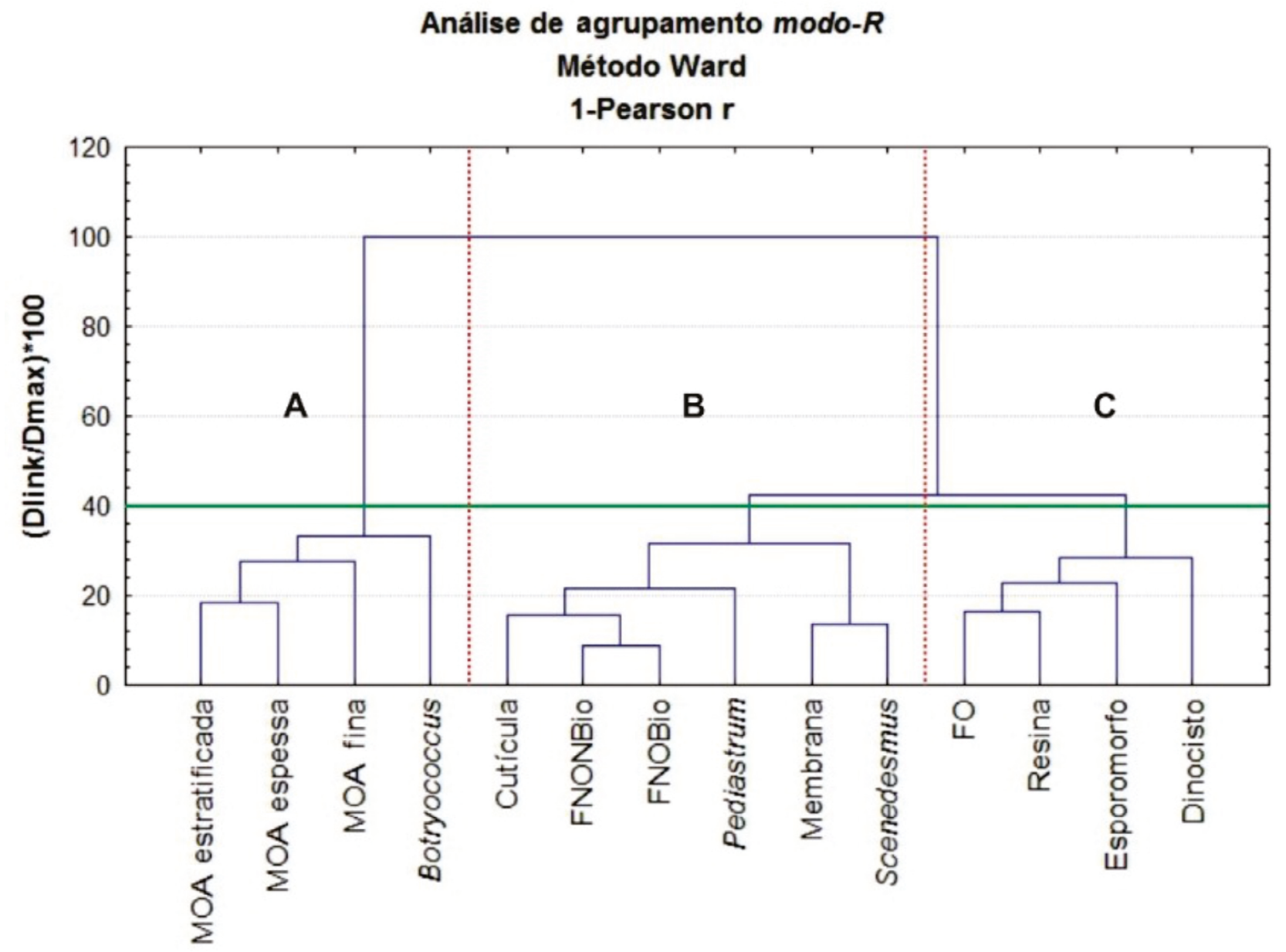

MOA: matéria orgânica amorfa; FNONBio: fitoclasto não opaco não bioestruturado; FNBio: fitoclasto não opaco bioestruturado; FO: fitoclasto opaco.

Figura 8. Dendrograma gerado pela análise de agrupamento modo- $R$ da palinofácies. 
Os esporos apresentam concentração entre 0,0 e $4,9 \%$. Botryococcus (0,0 a 3,5\%), Pediastrum $(0,0$ a $1,0 \%)$ e Scenedesmus $(0,0$ a $2,2 \%)$ ocorrem em baixas concentrações e de maneira restrita. No agrupamento G2 da contagem associada dos palinomorfos ocorre dominância do microplâncton marinho, representado pelos dinocistos (18,8 a $78,2 \%$ ). Os grãos de pólen também ocorrem com valores percentuais elevados $(20,1$ a $74,2 \%)$, os esporos possuem concentrações entre 0,0 e $8,1 \%$. Pediastrum e Botryococcus possuem proporções de 0,0 a $14,3 \%$ e de 0,0 a $6,3 \%$, respectivamente. Scenedesmus está ausente. O agrupamento G3 da contagem associada dos palinomorfos é caracterizado por dominância de grãos de pólen ( $43,0 \mathrm{a} 94,2 \%)$, seguidos pelos esporos (1,4 a 57,0\%). O microplâncton de água doce é representado por Botryococcus, Pediastrum e Scenedesmus, com concentrações entre 0,0 e $14,0 \% ; 0,0$ e $43,0 \%$ e entre 0,0 e $25,7 \%$, respectivamente. Nesse último agrupamento o microplâncton marinho (dinocistos) é ausente; com isso, os palinomorfos de origem continental representam $100,0 \%$ dos componentes totais.

\section{Análise organogeoquímica}

\section{Carbono Orgânico Total e teor de Enxofre Total}

Os resultados das análises de COT estão apresentados na Tabela 6, juntamente com os valores percentuais de St, em comparação com os intervalos estratigráficos identificados. Os valores mais elevados de COT ocorrem ao longo do Intervalo II, no qual a assembleia da matéria orgânica, representada pelas associações de palinofácies A e C, é dominada por MOA, mais especificamente MOA fina e MOA espessa, com registros expressivos de componentes de origem marinha (principalmente dinocistos). Nesse intervalo as concentrações de COT variam entre $0,31 \mathrm{e}$ $11,25 \%$, com média de $6,41 \%$.

O Intervalo IV, que apresenta assembleia da matéria orgânica composta pelas associações de palinofácies A, B e $C$, com predominância de fitoclastos não opacos não bioestruturados, MOA fina e dinocistos, possui valores de COT variando entre 0,10 e $0,53 \%$ (média de $0,25 \%$ ).

\section{Análise de agrupamento modo- $Q$ Método Ward \\ 1-Pearson $r$}

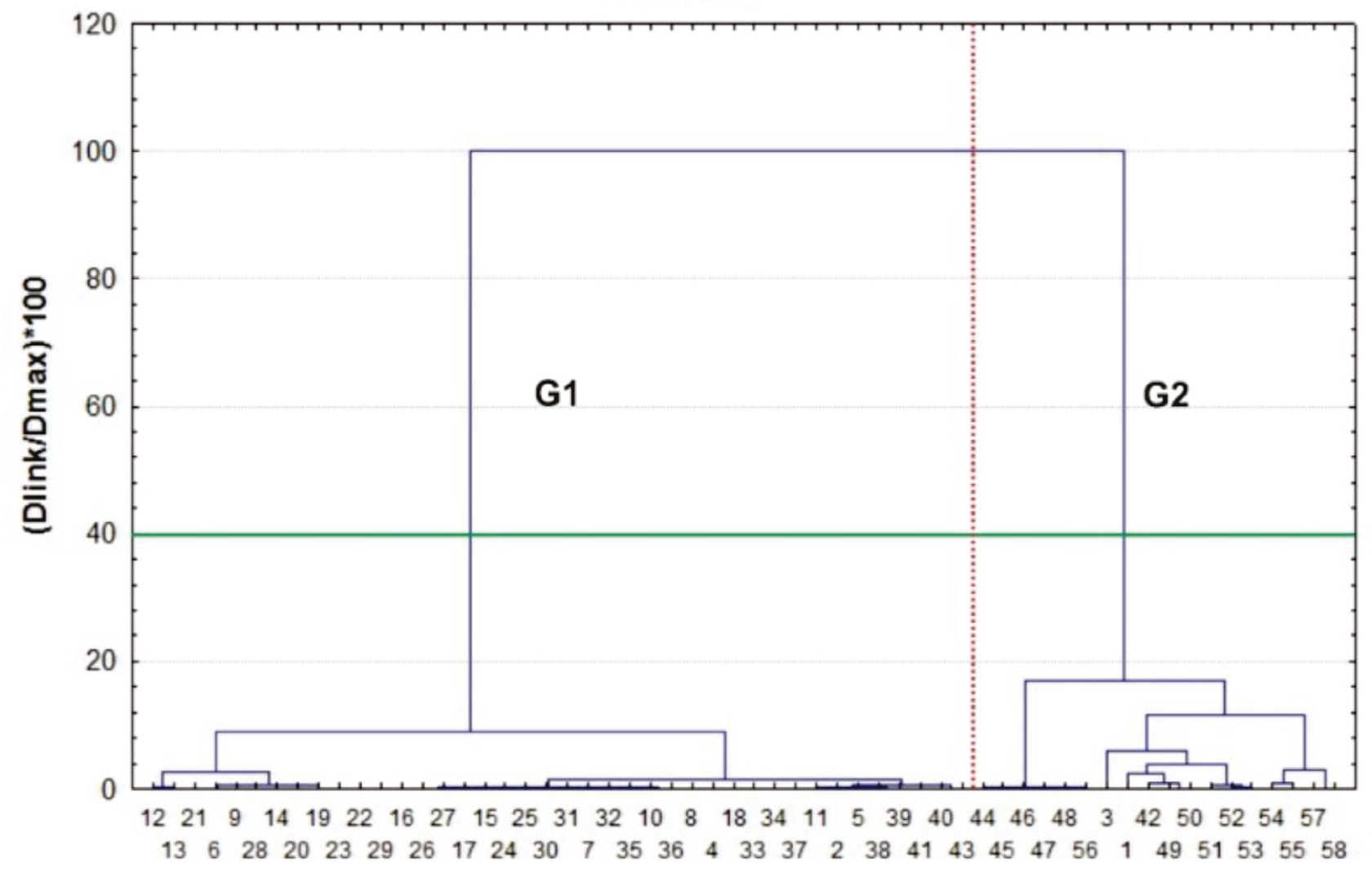

Figura 9. Dendrograma gerado pela análise de agrupamento modo- $Q$ da palinofácies. 
Nos demais intervalos - I, III e V -, representados por dominância do Grupo Fitoclasto, principalmente fitoclasto não opaco não bioestruturado (associações de palinofácies $\mathrm{B}$ e C), com ausência de componentes de origem marinha, os valores de COT também são mais reduzidos, variando entre 0,08 e $3,00 \%$, com média de $0,76 \%$.

\section{DISCUSSÃO DOS RESULTADOS}

\section{Palinofácies}

\section{Assembleia dominada pelo Grupo Amorfo}

A assembleia constituída por predominância de componentes amorfos ( 0,0 a 99,4\%) corresponde ao agrupamento G1 da Palinofácies (modo- $Q$; Figura 9). Também apresenta baixas concentrações e diversidades de esporomorfos, sendo representados principalmente por Classopollis e Cicatricosisporites. Valores elevados de COT $(0,15$ a $11,15 \%)$ estão associados a essa assembleia.
As elevadas quantidades de MOA — típicas de ambiente redutor - ocorrem de forma associada com elevadas concentrações de dinocistos - típicos de ambientes óxicos de alta produtividade primária -, o que sugere fortemente o estabelecimento de estratificação da coluna de água no ambiente de deposição dessa assembleia, como sugerido por Neumann et al. (2003) para o sistema lacustre do Grupo Santana (Formação Crato), que evoluiu sob um regime paleoclimático quente (tropical-subtropical) caracterizado por precipitação sazonal e alternância de ciclos úmidos e secos. Ainda de acordo com esses autores, o aumento do nível da água durante os episódios climáticos úmidos resultou no aprofundamento da coluna de água que, como consequência das condições climáticas, era propensa ao desenvolvimento de uma estratificação térmica permanente. As condições redutoras de fundo facilitaram tanto a preservação da MOA quanto de seus componentes lábeis, ricos em hidrogênio $(\mathrm{H})$, proporcionando, assim, fluorescência intensa para esses componentes (Tyson, 1993, 1995).

De acordo com Alvin (1982), o pólen Classopollis é característico da família Cheirolepidiaceae. Neumann et al. (2003) sugerem que as plantas que pertencem a essa família

\section{Análise de agrupamento modo- $Q$ Método Ward \\ Distância euclideana}

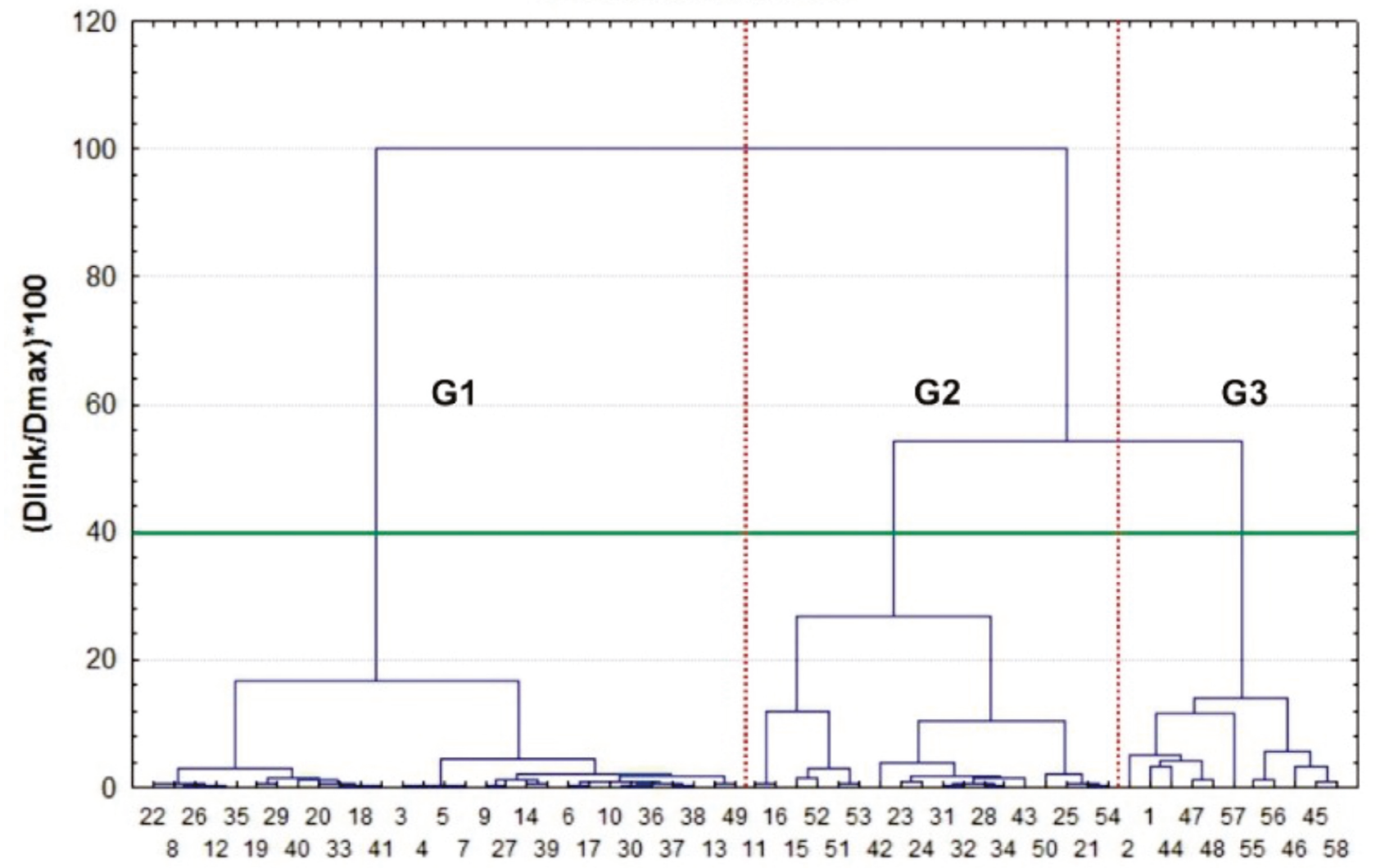

Figura 10. Dendrograma gerado pela análise de agrupamento modo-Q da contagem associada dos palinomorfos. 
eram onipresentes na Bacia do Araripe, com os grãos de pólen sendo facilmente transportados pelo vento e disseminados ao longo dos mais diversos ambientes deposicionais. O pólen Classopollis é relatado, abundantemente, em uma ampla gama de sedimentos, mas especialmente em ambientes costeiros, sob regimes climáticos áridos (Alvin, 1982). A concentração relativamente abundante de dinocistos indica a ocorrência de ingressões marinhas durante a deposição dessa assembleia. Arai e Coimbra (1990) identificaram vários níveis com a predominância de cistos de Subtilisphaera dentro do Grupo Santana, os quais podem indicar a ocorrência de florações fitoplanctônicas (blooms) em um ambiente marinho costeiro. A ocorrência restrita e em baixas concentrações do gênero Spiniferites (intervalos II e IV) indica, provavelmente, o estabelecimento de condições marinhas mais distais em momentos isolados (Harris e Tocher, 2003).

\section{Assembleia dominada pelo Grupo Fitoclasto}

A assembleia em questão, que corresponde ao agrupamento G2 da Palinofácies (modo- $Q$; Figura 9), é caracterizada por

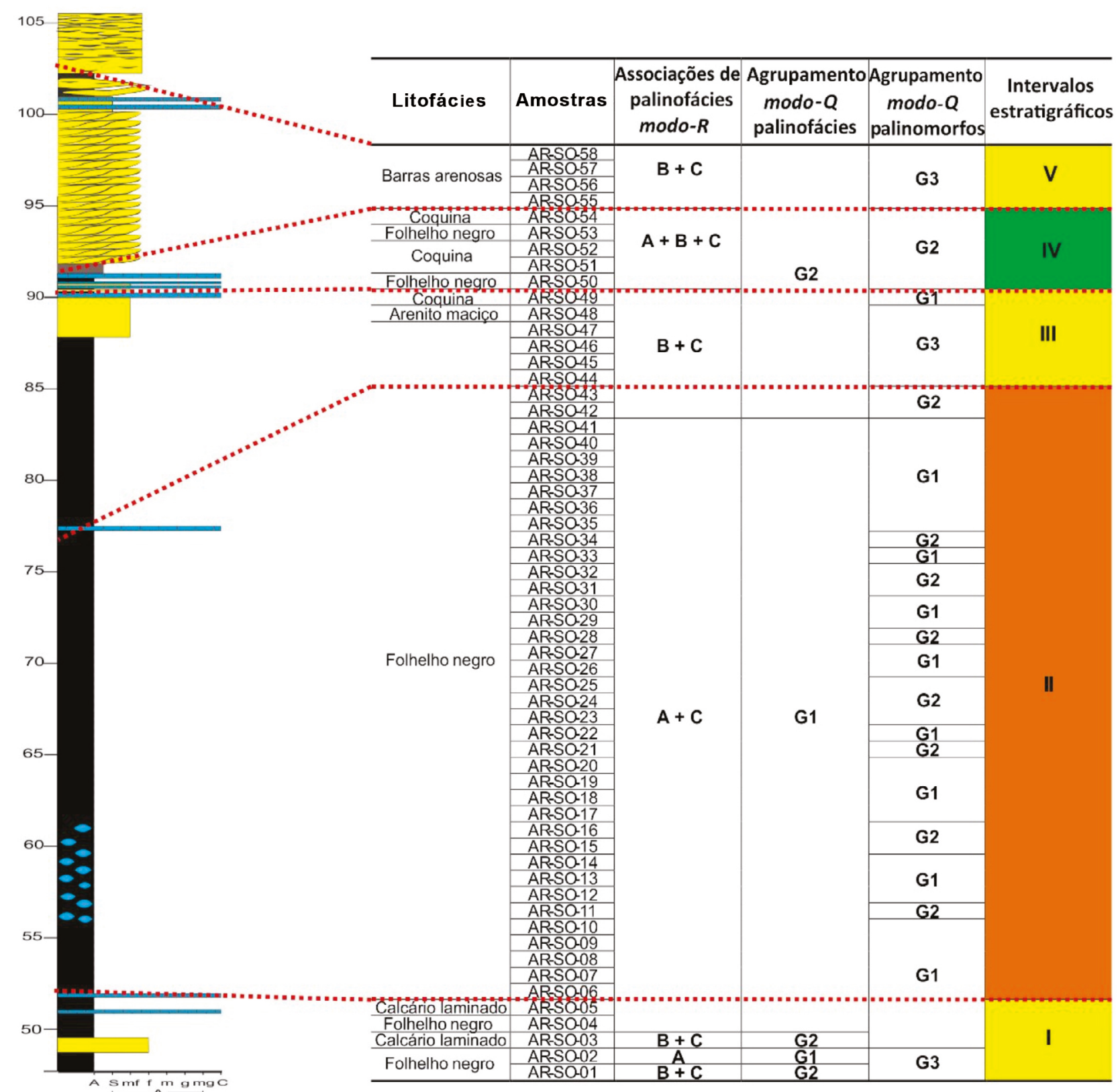

Figura 11. Resultados das análises de agrupamento modo- $R$ e modo- $Q$ com três associações de palinofácies e cinco intervalos estratigráficos. 
Tabela 6. Valores percentuais de Carbono Orgânico Total e teor de Enxofre Total.

\begin{tabular}{|c|c|c|c|c|}
\hline Litofácies & Amostras & Intervalos & Cot $(\%)$ & St (\%) \\
\hline \multirow{4}{*}{ Barras arenosas } & AR-SO-58 & \multirow{4}{*}{ V } & 0,08 & 0,01 \\
\hline & AR-SO-57 & & 0,12 & 0,05 \\
\hline & AR-SO-56 & & 2,22 & 0,10 \\
\hline & AR-SO-55 & & 0,55 & 0,01 \\
\hline Coquina & AR-SO-54 & \multirow{5}{*}{ IV } & 0,15 & 0,14 \\
\hline Folhelho & AR-SO-53 & & 0,53 & 0,02 \\
\hline \multirow{2}{*}{ Coquina } & AR-SO-52 & & 0,10 & 0,12 \\
\hline & AR-SO-51 & & 0,10 & 0,10 \\
\hline Folhelho & AR-SO-50 & & 0,36 & 0,02 \\
\hline Coquina & AR-SO-49 & \multirow{6}{*}{ III } & 0,15 & 0,11 \\
\hline Arenito maciço & AR-SO-48 & & 0,58 & 0,30 \\
\hline \multirow{42}{*}{ Folhelho } & AR-SO-47 & & 0,42 & 0,21 \\
\hline & AR-SO-46 & & 0,75 & 0,06 \\
\hline & AR-SO-45 & & 0,91 & 0,20 \\
\hline & AR-SO-44 & & 0,45 & 0,01 \\
\hline & AR-SO-43 & \multirow{38}{*}{ ॥ } & 0,94 & 0,46 \\
\hline & AR-SO-42 & & 0,33 & 0,03 \\
\hline & AR-SO-41 & & 0,31 & 0,02 \\
\hline & AR-SO-40 & & 1,96 & 0,91 \\
\hline & AR-SO-39 & & 2,79 & 0,32 \\
\hline & AR-SO-38 & & 3,05 & 0,36 \\
\hline & AR-SO-37 & & 3,16 & 0,33 \\
\hline & AR-SO-36 & & 5,45 & 0,58 \\
\hline & AR-SO-35 & & 6,63 & 0,71 \\
\hline & AR-SO-34 & & 7,81 & 0,86 \\
\hline & AR-SO-33 & & 5,81 & 0,86 \\
\hline & AR-SO-32 & & 9,10 & 1,15 \\
\hline & AR-SO-31 & & 8,67 & 1,21 \\
\hline & AR-SO-30 & & 9,62 & 1,42 \\
\hline & AR-SO-29 & & 9,70 & 1,38 \\
\hline & AR-SO-28 & & 8,90 & 1,50 \\
\hline & AR-SO-27 & & 7,25 & 1,08 \\
\hline & AR-SO-26 & & 5,93 & 1,14 \\
\hline & AR-SO-25 & & 6,54 & 1,38 \\
\hline & AR-SO-24 & & 7,24 & 1,50 \\
\hline & AR-SO-23 & & 7,65 & 1,15 \\
\hline & AR-SO-22 & & 8,18 & 1,46 \\
\hline & AR-SO-21 & & 9,05 & 1,82 \\
\hline & AR-SO-20 & & 8,15 & 2,30 \\
\hline & AR-SO-19 & & 6,58 & 1,65 \\
\hline & AR-SO-18 & & 3,85 & 1,15 \\
\hline & AR-SO-17 & & 5,55 & 1,35 \\
\hline & AR-SO-16 & & 5,63 & 1,69 \\
\hline & AR-SO-15 & & 7,00 & 2,06 \\
\hline & AR-SO-14 & & 7,92 & 2,20 \\
\hline & AR-SO-13 & & 8,82 & 2,78 \\
\hline & AR-SO-12 & & 11,25 & 2,72 \\
\hline & AR-SO-11 & & 4,71 & 1,95 \\
\hline & AR-SO-10 & & 6,30 & 1,25 \\
\hline & AR-SO-09 & & 10,76 & 1,45 \\
\hline & AR-SO-08 & & 7,49 & 1,73 \\
\hline & AR-SO-07 & & 7,32 & 1,45 \\
\hline & AR-SO-06 & & 6,26 & 1,15 \\
\hline Calcário laminado & AR-SO-05 & & 0,28 & 0,35 \\
\hline Folhelho & AR-SO-04 & & 3,00 & 0,69 \\
\hline Calcário laminado & AR-SO-03 & I & 0,13 & 2,19 \\
\hline & AR-SO-02 & & 1,24 & 1,11 \\
\hline Folhelho & AR-SO-01 & & 0,45 & 0,08 \\
\hline
\end{tabular}

COT: Carbono Orgânico Total; St: Enxofre Total. 
abundância de componentes lenhosos do Grupo Fitoclasto $(46,5$ a $96,4 \%)$ e também quantidades mais elevadas de esporomorfos, com maior diversidade de gêneros e espécies. Valores mais baixos de COT ( 0,08 a 2,22\%) estão associados a essa assembleia.

Assembleias de componentes orgânicos particulados dominadas por fitoclastos não opacos não bioestruturados são características de deposição em fácies altamente proximais, em locais onde a deposição ocorre muito próximo à flora-mãe, visto que existe uma sequência natural de destruição dos fitoclastos, de acordo com o teor de lignina e com a resistência inerente à destruição e, assim sendo, os primeiros componentes a desaparecer são os não opacos não bioestruturados (Tyson, 1993, 1995; Mendonça Filho et al., 2011). Percentagens mais elevadas de fitoclastos não opacos são usualmente encontradas próximas de fontes fluviais, onde tais partículas diluem qualquer tipo de fitoclasto opaco, palinomorfos e MOA que esteja presente (Tyson, 1995; Mendonça Filho et al., 2010a, 2011). A concentração também significativa de fitoclastos opacos reflete condições ambientais oxidantes e de alta energia (Tyson, 1993), o que é corroborado ainda pelo fato destes serem representados principalmente por partículas corroídas.

Percentagens elevadas de esporomorfos são encontradas em áreas proximais, adjacentes à flora-mãe, onde a entrada de esporos e grãos de pólen é alta, refletindo uma paleopalinoflora de alta variabilidade, localmente derivada (Tyson, 1993). A maior diversidade morfológica de esporos e grãos de pólen indica a predominância de um clima quente, em razão da ocorrência de formas típicas, como Classopollis, Equisetosporites, Gnetaceaepollenites, Sergipea, Afropollis e Cicatricosisporites, também reportadas por Neumann et al. (2003) e Portela et al. (2014). A ocorrência de um clima mais seco é ainda corroborada pela existência de cutículas com estômatos bem preservados, atribuídas à família Cheirolepidiaceae (Alvin, 1982), a qual é bem adaptada a regiões áridas de baixa paleolatitude.

A ocorrência de Sergipea variverrucata nas amostras AR-SO-01, na base do perfil, e AR-SO-46, AR-SO-50, AR-SO-56 e AR-SO-58, no topo do perfil, permite o posicionamento cronoestratigráfico da seção litológica estudada no Aptiano Superior, visto que, de acordo com Regali et al. (1974), esse grão de pólen é indicativo da Palinozona Sergipea variverrucata (P-270), relacionada a essa idade. Segundo Regali e Viana (1989) e Regali e Santos (1999), o limite Aptiano/Albiano se dá bem acima da extinção de $S$. variverrucata, portanto, a ocorrência desse táxon limita o perfil estudado ao Aptiano Superior.

As proporções consideráveis do microplâncton de água doce representam proximidade relativa de áreas flúvio-deltáicas. Batten (1996) postula que Pediastrum e Scenedesmus são abundantes sob condições fortemente eutróficas, tipicamente em rios, poças e lagos de água doce. Botryococcus é considerado um indicador paleoambiental de sistema lacustre de água doce a salobro.

\section{Origem da matéria orgânica amorfa}

De acordo com os dados expostos na descrição da MOA, foi observada a ocorrência de três tipos principais, assim denominados: MOA fina, MOA espessa e MOA estratificada. Os dois primeiros tipos são extremamente frequentes e abundantes na maioria das amostras analisadas; a MOA estratificada, no entanto, ocorre em baixíssimas concentrações e está restrita a algumas amostras da porção mediana do perfil (AR-SO-06, AR-SO-09, AR-SO-12 e AR-SO-14).

A MOA fina é caracterizada por apresentar aspecto granular fino (lenticular), quase transparente, exibindo fluorescência intensa a moderada. Já a MOA espessa é caracterizada principalmente pelo seu aspecto granular espesso, mais encorpado, com contornos irregulares a retilíneos, por vezes formando arestas; a intensidade da fluorescência é moderada a forte. Tanto a MOA fina quanto a espessa apresentam íntima associação com tecidos vegetais degradados ou em estado de amorfização, tratando-se principalmente de cutículas e fitoclastos não opacos. Verifica-se também a ocorrência de inclusões de pirita e de grânulos fluorescentes, além da presença de estruturas semelhantes a crateras. De acordo com tais evidências, esse material pode ser derivado do intenso retrabalhamento bacteriano de tecidos vegetais. $O$ fato desses componentes ocorrerem associados a pirita evidencia a atividade de bactérias sulfato-redutoras (Berner et al., 1985), as quais podem ser responsáveis pela decomposição de substâncias exopoliméricas (EPS), associadas a esteiras microbianas (Martill, 1988). A ocorrência expressiva de esteiras microbianas no sistema deposicional dos folhelhos da Formação Romualdo foi verificada por Martill (1988), que sugeriu que tais estruturas poderiam contribuir para os mais altos valores de matéria orgânica (COT), denotando uma baixa diluição dos componentes orgânicos por material siliciclástico.

A presença de MOA estratificada, apresentando padrão interno estruturado, com finas camadas de material amorfo sobrepostas umas às outras, mostrando diminutas crateras dispostas preferencialmente no entremeio das finas camadas, provavelmente oriundas da dissolução de grãos carbonáticos, sugere que esse material possua uma origem bacteriana, estando relacionado à ocorrência de esteiras microbianas no ambiente (Tyson, 1995; Mendonça Filho et al., 2010a).

As baixíssimas concentrações de MOA bacteriana (MOA estratificada) na Formação Romualdo podem ser atribuídas ao intenso consumo, por bactérias heterotróficas, do produto que originaria tal partícula, de acordo com Furukawa (2014). Em condições anaeróbicas e na ausência de organismos pastadores, o material produzido por microrganismos produtores pode ser exaurido em meses, por meio do consumo de bactérias presentes no próprio consórcio bacteriano (Doemel 
e Brock, 1977). Contudo, ligninas, porfirinas, hidrocarbonetos alifáticos e alguns outros constituintes comumente encontrados em tecidos vegetais não são decompostos nas condições descritas, o que explicaria a presença maciça de MOA de origem vegetal (Furukawa, 2014).

A fluorescência intensa está relacionada às condições disóxica-anóxicas que facilitam a preservação de componentes lábies da MOA, ricos em H (Tyson, 1993, 1995). De acordo com Neumann et al. (2003), o intenso retrabalhamento bacteriano dos tecidos vegetais, com a possível incorporação de biomassa bacteriana, pode ser responsável pelo enriquecimento em $\mathrm{H}$.

\section{Retrabalhamento do Paleozoico}

A ocorrência de componentes de idade Paleozoica nos sedimentos cretácicos estudados é atribuída à atuação de erosão de sedimentos devonianos da Bacia do Parnaíba e à redeposição na Bacia do Araripe (Brito e Quadros, 1995), ou seja, esses componentes são oriundos de retrabalhamento. De acordo com Tyson (1995), a presença de palinomorfos retrabalhados indica deposição adjacente — ou redeposição a partir de áreas de erosão ativa, especialmente sob climas úmidos -, e também proximidade de fontes flúvio-deltáicas de sedimentação siliciclástica, caracterizando fácies regressiva, depositada durante nível de mar baixo.

No presente trabalho, foi registrada a ocorrência de palinomorfos retrabalhados nas amostras AR-SO-01, AR-SO02 e AR-SO-03, na base do perfil (Intervalo I); AR-SO-37 e AR-SO-42, no topo do Intervalo II; e AR-SO-44, AR-SO46 e AR-SO-47, pertencentes ao Intervalo III. Pons et al. (1996) e Rios-Netto (2011) observaram que palinomorfos retrabalhados são abundantes nas Camadas Batateira, porém são mais raros nas formações Crato, Ipubi e Romualdo, e correlacionaram essas ocorrências com medidas de paleocorrentes disponíveis na literatura.
Medidas de paleocorrentes obtidas em arenitos fluviais da Formação Barbalha (Assine, 1994; Chagas, 2006) indicaram que a fonte principal dos sedimentos estaria a NW. Para a Formação Romualdo, as medidas indicaram uma mudança significativa na direção das paleocorrentes (Chagas, 2006), e área-fonte principal a NE. Rios-Netto (2011) argumentou que os depósitos devonianos marinhos da Bacia do Parnaíba estão situados a NW, observando uma correlação coerente entre essa provável mudança de área-fonte e a maior variação na concentração de material devoniano retrabalhado nas Camadas Batateiras, fato também observado por Pons et al. (1996).

\section{Interpretação paleoambiental dos intervalos estratigráficos}

Com base na divisão em intervalos estratigráficos (Figura 12), observou-se que a variação nas concentrações dos subgrupos da matéria orgânica particulada está diretamente relacionada aos períodos de maior ou menor disponibilidade de material orgânico de origem marinha, ou seja, demonstrando ciclicidade no padrão de suprimento do material orgânico. Essa ciclicidade, evidenciada pela separação dos intervalos, está provavelmente relacionada a oscilações do nível relativo do mar durante o Aptiano-Albiano, que influenciaram o suprimento de material orgânico de origem terrestre.

Essa afirmação é condizente com a teoria proposta por Arai e Coimbra (1990), que postula que a ingressão marinha aptiana teria ocorrido de forma pulsativa, mantendo o ambiente mixohalino em razão das variações na paleofauna de ostracodes em associação com assembleias de dinocistos.

A reconstrução paleoambiental foi baseada na integração dos dados de palinofácies, que forneceu uma estimativa mais apurada das tendências proximais-distais. Para isso, foram utilizados o diagrama ternário MFP (Figura 13) e o diagrama de dados percentuais de Esporos-Dinocistos-Grãos

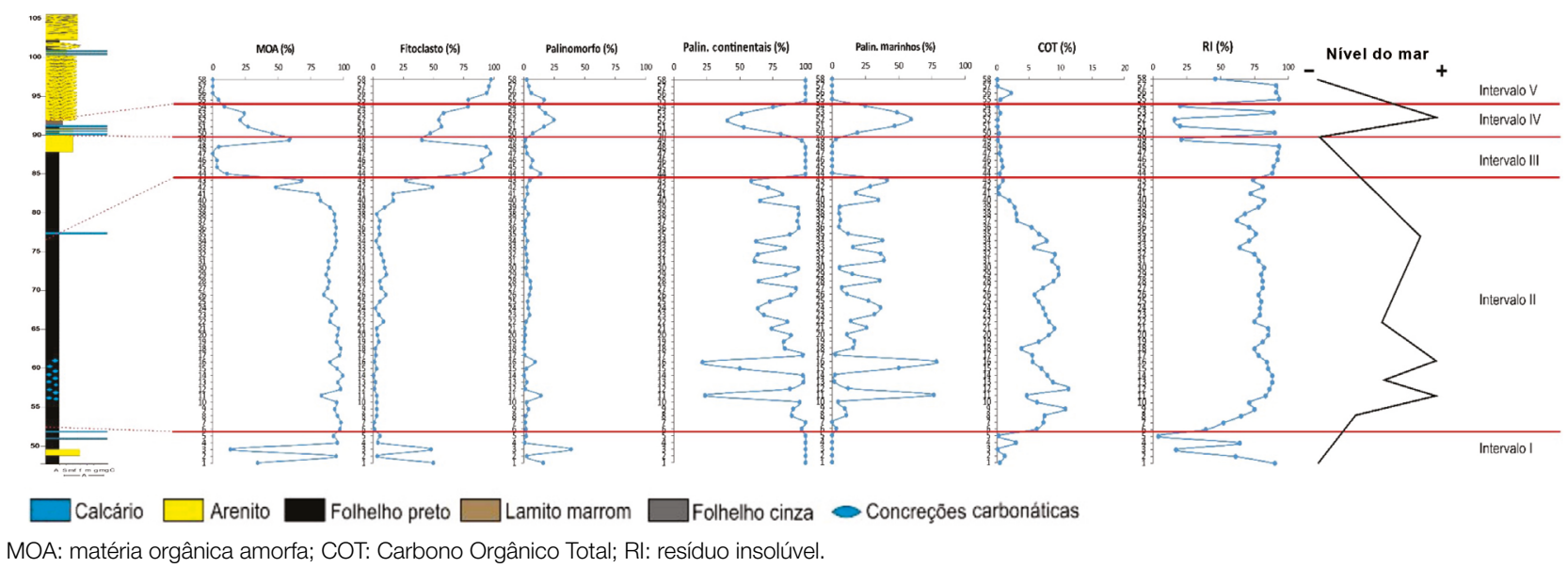

Figura 12. Parâmetros palinofaciológicos e organogeoquímicos utilizados para traçar a curva de variação do nível relativo do mar para o perfil analisado. 
de Pólen para indicar a proximidade da área-fonte continental e de ambientes deposicionais onshore-offshore, como também a tendência transgressivo-regressiva (Figura 14A) (Tyson, 1993, 1995; Mendonça Filho et al., 2011). As condições de salinidade nos sítios deposicionais são indicadas pelo diagrama ternário MOA-Chlorococcales (Figura 14B), que também é indicado para distinguir o estado trófico em ambientes lacustres (Mendonça Filho et al., 2011).

\section{Intervalo I (amostras AR-SO-01 a AR-SO-05)}

Intervalo alocado na extrema base da seção colunar Sobradinho, englobando as litofácies folhelho negro e

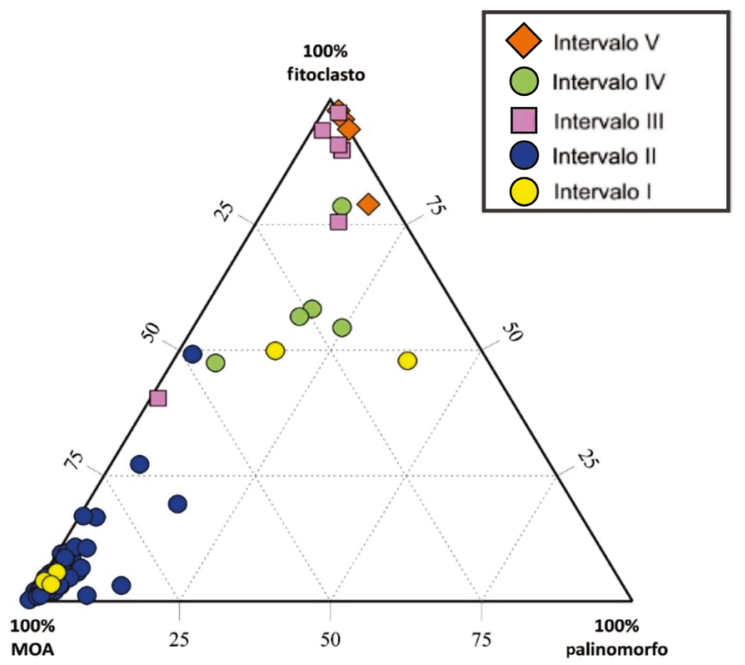

MOA: matéria orgânica amorfa.

Figura 13. Diagrama ternário MOA-Fitoclasto-Palinomorfo. calcário laminado. Apresenta abundância de fitoclastos não opacos e de palinomorfos de origem continental; as concentrações de MOA são razoáveis, tornando-se mais abundante nas amostras em que o suprimento de fitoclastos e esporomorfos provavelmente diminuiu.

Esse intervalo apresenta características de deposição altamente proximal, com grande influência de aporte continental na deposição da matéria orgânica sedimentar (Figuras 13 e 14A). Os elevados valores de MOA ocorrem associados com componentes de origem lacustre de água doce, o que sugere a ocorrência de estratificação da coluna de água, com anoxia de fundo, facilitando a preservação da MOA, em um ambiente lacustre, com variações recorrentes na salinidade (Figura 14B), como observado por Neumann et al. (2003). Observa-se, ainda, ao longo desse intervalo, a ocorrência de componentes retrabalhados do Paleozoico, mais um indicativo da contribuição do aporte continental na deposição dos componentes orgânicos para esse intervalo. Os valores mais elevados de COT estão associados à baixa taxa de diluição dos componentes orgânicos por material siliciclástico.

\section{Intervalo II (amostras AR-SO-06 a AR-SO-43)}

O Intervalo II é caracterizado por uma espessa camada de folhelho negro, englobando todo o nível de concreções carbonáticas, na porção mediana do perfil. Esse intervalo marca o estabelecimento de condições relativamente estáveis de deposição da matéria orgânica sedimentar, sob fácies de caráter mais distal a intermediário (Figura 13), com drástica redução do aporte continental e aparecimento da influência de componentes marinhos (Figura 14A), possivelmente

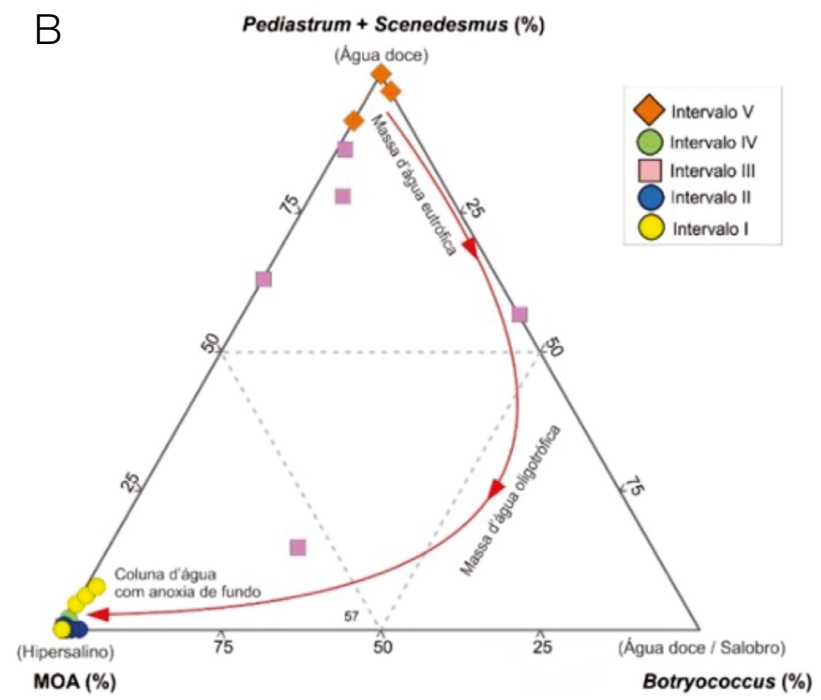

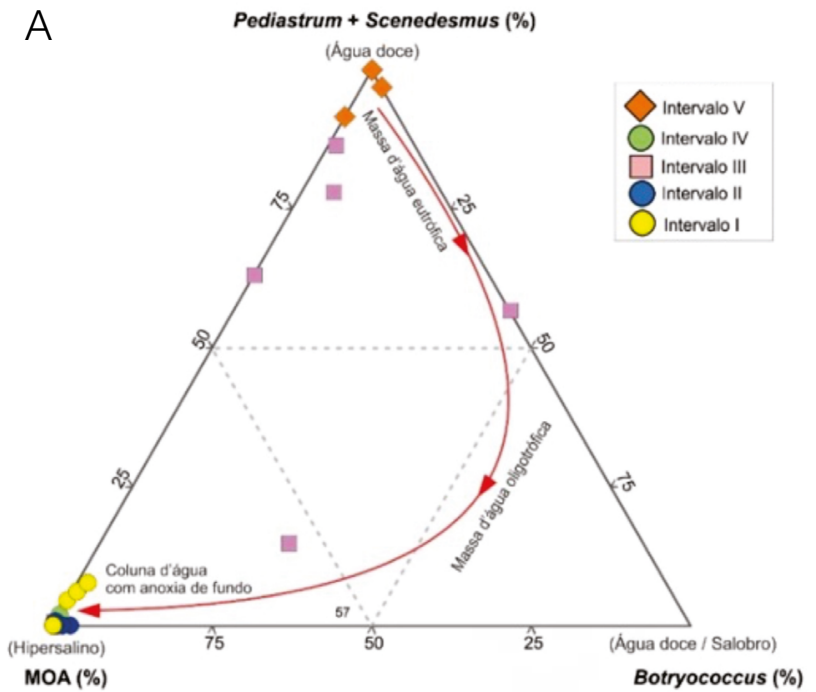

MOA: matéria orgânica amorfa.

Figura 14. (A) Diagrama ternário Esporos-Dinocistos-Grãos de Pólen; (B) diagrama ternário MOA-Chlorococcales (modificado de Mendonça Filho et al., 2011). 
um ambiente marinho restrito. A elevada concentração de MOA, bem preservada e com fluorescência intensa, indica condições ambientais de caráter redutor em um estado de estratificação da coluna de água, sob condições de salinidade elevada (Figura 14B).

Ao final do intervalo, observa-se a ocorrência de componentes de idade Paleozoica, como também o aumento na concentração dos fitoclastos, marcando o retorno da influência do aporte continental na deposição dos componentes orgânicos. Esse intervalo mostra valores elevados de COT, que estão associados com altas concentrações de MOA, evidenciando o baixo suprimento de material siliciclástico e a consequente menor diluição dos componentes orgânicos (Tyson, 1995).

Notou-se nesse intervalo que a tendência geral do nível do mar é de elevação e posterior estabilidade, caracterizando uma ingressão marinha na Bacia do Araripe. O topo do intervalo é marcado por rebaixamento do nível médio do mar e retorno das condições mais proximais de deposição da matéria orgânica.

\section{Intervalo III (amostras AR-SO-44 a AR-SO-49)}

Esse intervalo, rico em fitoclastos não opacos e esporomorfos, ocorre distribuído pelas litofácies folhelho negro, arenito maciço e coquina. Marca o retorno de condição altamente proximal de deposição da matéria orgânica sedimentar, com elevado aporte de componentes de origem continental e ausência de componentes marinhos. Ao longo desse intervalo ocorrem componentes de idade Paleozoica, oriundos de retrabalhamento.

O Intervalo III é característico de um ambiente altamente proximal (Figuras 13 e 14A), no qual o elevado suprimento de fitoclastos dilui todos os outros componentes, mas a influência de um ambiente disóxico-anóxico possibilitou moderada preservação de MOA, sugerindo a instalação de um ambiente lacustre, com possível estratificação da coluna de água. O diagrama MOA-Chlorococcales (Figura 14B) mostra a influência de ambiente predominantemente de água doce, com massa de água eutrófica. A alta diluição da matéria orgânica por sedimentos é, possivelmente, a causa dos baixos valores de COT, de acordo com Tyson (1995).

\section{Intervalo IV (amostras AR-SO-50 a AR-SO-54)}

Esse intervalo é caracterizado litologicamente pela intercalação das litofácies folhelho negro e coquina, apresentando os componentes lenhosos como dominantes, principalmente fitoclasto não opaco não bioestruturado e fitoclastos opacos, seguidos por MOA e concentrações consideráveis de componentes marinhos (dinocistos e palinoforaminíferos). Os dinocistos são representados pelos gêneros Subtilisphaera e Spiniferites, com o primeiro sendo extremamente dominante.
Dentre todos os intervalos identificados, o Intervalo IV é o único que apresenta tendência de deposição da matéria orgânica sedimentar em condições fortemente proximais, mas com elevada influência de componentes marinhos. Esse intervalo evidencia um ambiente transicional proximal-distal (Figuras 13 e 14A). Condições redutoras propiciaram boa taxa de preservação da MOA. O alto suprimento de fitoclastos evidencia proximidade da flora-mãe. Esse intervalo também demonstra a ocorrência de estratificação da coluna d'água, com anoxia de fundo, de acordo com o diagrama MOA-Chlorococcales (Figura 14B). A existência de componentes marinhos, associados com quantidades mais elevadas de MOA, sugere a influência de um ambiente mais distal, possivelmente marinho costeiro, devido, principalmente, à abundância de dinocistos do gênero Subtilisphaera, caracterizando a ocorrência de nova ingressão marinha na Bacia do Araripe (Arai e Coimbra, 1990; Arai et al., 2000; Arai, 2014).

\section{Intervalo V (amostras AR-SO-55 a AR-SO-58)}

Esse intervalo representa o topo da seção colunar Sobradinho, estando distribuído pelos arenitos da litofácies barras arenosas. Apresenta características de deposição altamente proximal, com grande influência de aporte continental na deposição da matéria orgânica sedimentar devido ao elevado conteúdo de fitoclastos, esporomorfos e microplâncton de água doce, como também a ausência de componentes de origem marinha.

O Intervalo $\mathrm{V}$ evidencia um ambiente óxico, altamente proximal, com baixíssima preservação de MOA (Figuras 13 e 14A). O elevado suprimento de fitoclastos dilui todos os outros componentes, e a abundância absoluta desses componentes reflete a proximidade de fontes flúvio-deltaicas, em um ambiente de água doce, com massa de água eutrófica (Figura 14B). Os baixos valores de COT são devidos, principalmente, à alta taxa de diluição dos componentes orgânicos pelo aporte elevado de material siliciclástico.

\section{CONCLUSÕES}

Com base nas análises palinofaciológicas e organogeoquímicas realizadas nas amostras pertencentes à Formação Romualdo, verificou-se a existência de duas assembleias distintas de componentes orgânicos particulados. A primeira é caracterizada por dominância de MOA derivada de tecidos vegetais, intensamente fluorescente, com quantidades relativamente elevadas de componentes de origem marinha (dinocistos e palinoforaminíferos), representando condições mais distais de deposição da matéria orgânica. A segunda assembleia é caracterizada por dominância de componentes lenhosos do Grupo Fitoclasto, predominando o subgrupo do fitoclasto 
não opaco não bioestruturado; essa assembleia representa deposição em fácies altamente proximais, em locais onde a deposição ocorre muito próximo à flora-mãe.

A subdivisão do perfil litológico estudado em cinco intervalos estratigráficos possibilitou a verificação de variações no padrão de suprimento do material orgânico, relacionadas a oscilações do nível relativo do mar. Os períodos de rebaixamento do nível relativo do mar são marcados por valores percentuais mais elevados de componentes orgânicos de origem continental. Já nos períodos de elevação do nível relativo do mar ocorre o aumento dos valores percentuais de MOA e de componentes de origem marinha.

Dois eventos de ingressão marinha, durante a deposição da Formação Romualdo, foram identificados e caracterizados. A primeira ingressão é representada pelo Intervalo II, que engloba quase todo o espesso pacote de folhelho negro portador de concreções carbonáticas, situado na porção mediana do Perfil Sobradinho, marcando o estabelecimento de condições relativamente estáveis de deposição da matéria orgânica sedimentar, de caráter mais distal a intermediário, em contexto de mar raso epicontinental. A segunda ingressão marinha é representada pelo Intervalo IV, situado no topo do perfil e caracterizado litologicamente por intercalação das litofácies folhelho negro e coquina. Esse intervalo apresenta tendência de deposição da matéria orgânica sedimentar em condições bastante proximais, mas com elevada influência de componentes de origem marinha, evidenciando um ambiente marinho costeiro transicional proximal-distal.

\section{REFERÊNCIAS}

Alvin, K. L. (1982). Cheirolepidiaceae: biology, structure and palaeoecology. Palaeobot. Palynol. 37, 71-98.

American Society for Testing and Materials-ASTM. (2008). Standard Test Methods for Sulfur in the Analysis Sample of Coal and Coke Using High-Temperature Tube Furnace Combustion Methods. ASTM International.

Arai, M. (2014). Aptian/Albian (Early Cretaceous) paleogeography of the South Atlantic: a paleontological perspective. Brazilian Journal of Geology, 44(2), 339-350.

Arai, M., Botelho Neto, J., Lana, C. C., Pedrão, E. (2000). Cretaceous dinoflagellate provincialism in Brazilian marginal basins. Cretaceous Research, 21(2/3), 351-366.

Arai, M., Coimbra, J.C. (1990). Análise paleoecológica do registro das primeiras ingressões marinhas na Formação Santana (Cretáceo Inferior da Chapada do Araripe). Simpósio Bacia do Araripe e Bacias Interiores do Nordeste, v. 1, 225-240. Crato: DNPM.
Assine, M. L. (1990). Sedimentação e tectônica da Bacia do Araripe (Nordeste do Brasil). Dissertação (Mestrado). Rio Claro: Instituto de Geociências e Ciências Exatas - UNESP.

Assine, M. L. (1992). Análise estratigráfica da Bacia do Araripe, Nordeste do Brasil. Revista Brasileira de Geociências, 22, 289-300.

Assine, M. L. (1994). Paleocorrentes e paleogeografia na Bacia do Araripe, Nordeste do Brasil. Revista Brasileira de Geociências, 24(4), 1-10.

Assine, M. L. (2007). Bacia do Araripe. Boletim de Geociências da Petrobras, 15(2), 371-389.

Assine, M. L., Perinotto, J. A. J., Neumann, V. H., Custódio, M. A., Varejão, F. G., Mescolotti, P. C. (2016). Sequências Deposicionais do Andar Alagoas (Aptiano superior) da Bacia do Araripe, Nordeste do Brasil. Boletim de Geociências da Petrobras, 22(1), 3-28.

Batten, D. J. (1996). Colonial Chlorococcales. In: J. Jansonius, D. C. McGregor (Eds.), Palynology: Principles and Applications (v. 1, 191-203). Salt Lake City: American Association of Stratigraphic Palynologists Foundation.

Berner, R. A., Leeuw, J. W., Spiro, B., Murchison D. G., Eglinton, G. (1985). Sulfate reduction, organic matter decomposition and pyrite formation. Philosophical Transactions of the Royal Society of London, 315, 25-37.

Brito, I. M., Quadros, L. P. (1995). Retrabalhamento do Devoniano no Cretáceo Inferior da Bacia do Araripe. Anais da Academia Brasileira de Ciências, 67(4), 493-496.

Carvalho, M. A. (2001). Paleoenvironmental reconstruction based on palynological and palynofacies analyses of the Aptian-Albian succession in the Sergipe Basin, Northeastern, Brazil. Thesis (Doctorate). Heidelberg: NaturwissenschaftlichMathematischen Gesamtfakultät der Ruprecht-KarlsUniversität Heidelberg.

Chagas, D. B. (2006). Litoestratigrafia da Bacia do Araripe: reavaliação e proposta para revisão. Dissertação (Mestrado). Rio Claro: Instituto de Geociências e Ciências Exatas - UNESP.

Coimbra, J. C., Arai, M., Carreño, A. L. (2002). Biostratigraphy of Lower Cretaceous microfossils from the Araripe Basin, Northeastern Brazil. Geobios, 35(6), 687-698. 
Dias-Brito, D., Tibana, P., Assine, M., Neumann, V. H. L. (2015). Calcários lagunares Romualdo: Bacia do Araripe, Aptiano superior - Albiano inferior. In: D. Dias-Brito, P. Tibana (Eds.), Calcários do Cretáceo do Brasil: um Atlas (v. 1, 135-157). Rio Claro: UNESP/UNESPetro.

Doemel, W. N., Brock, T. D. (1977). Structure, growth and decomposition of laminated algal-bacterial mats in alkaline hot springs. Applied Environmental Microbiology, 34, 433-452.

Furukawa, G. G. (2014). Caracterização e correlação da matéria orgânica (particulada e molecular) em sedimentos e rochas sedimentares com diferente conteúdo carbonático. Dissertação (Mestrado). Rio de Janeiro: Instituto de Geociências - UFRJ.

Harris, A. J., Tocher, B. A. (2003). Palaeoenvironmental analysis of Late Cretaceous dinoflagellate cyst assemblages using high-resolution sample correlation from the Western Interior Basin, USA. Marine Micropaleontology, 48, 127-148.

Kellner, A. W. A. (2002). Membro Romualdo da Formação Santana, Chapada do Araripe, CE. Um dos mais importantes depósitos fossilíferos do Cretáceo brasileiro. In: C. Schobbenhaus, D. A. Campos, E. T. Queiroz; M. Winge; M. L. C. Berbert-Born (Eds.), Sítios geológicos e paleontológicos do Brasil (v. 1, 121-130). Brasília: DNPM/CPRM/SIGEP.

Mabesoone, J. M., Tinoco, I. M. (1973). Paleoecology of Aptian Santana Formation (Northeastern Brazil). Palaeogeography, Palaeoclimatology, Palaeoecology, 14(2), 87-118.

Maisey, J. G. (1991). Santana Fossils: An Illustrated Atlas. Pennsylvania: TFH Publishers.

Martill, D. M. (1988). Preservation of fish in the Cretaceous Santana Formation of Brazil. Palaeontology, 30, 1-18.

Martill, D. M., Bechly, G., Loveridge, R. F. (2007). The Crato Fossil Beds of Brazil: window into an ancient world. Cambridge: Cambridge University Press.

Martill, D. M., Brito, P. M., Washington-Evans, J. (2008). Mass mortality of fishes in the Santana Formation (Lower Cretaceous, ?Albian) of northeast Brazil. Cretaceous Research, 29, 649-658.

Mendonça Filho, J. G. (1999). Aplicação de estudos de palinofácies e fácies Orgânica em rochas do Paleozóico da Bacia do Paraná, Sul do Brasil. Tese (Doutorado). Porto Alegre: UFRGS.
Mendonça Filho, J. G., Chagas, R. B. A., Menezes, T. R., Mendonça, J. O., da Silva, F. S., Sabadini-Santos, E. (2010a). Organic facies of the Oligocene lacustrine system in the Cenozoic Taubaté Basin, Southern Brazil. International Journal of Coal Geology, 84, 166-178.

Mendonça Filho, J. G., Menezes, T. R., Mendonça, J. O., Oliveira, A. D., Carvalho, M. A., Sant'Anna, A. J., Souza, J. T. (2010b). Palinofácies. In: I. S. Carvalho (Ed.), Paleontologia: conceitos e métodos (v. 2, 379-413). Rio de Janeiro: Interciência.

Mendonça Filho, J. G., Menezes, T. R., Mendonça, J. O., Oliveira, A. D., Sant'Anna, A. J. (2011). Kerogen: Composition and Classification. In: D. Flores, M. Marques (Eds.), ICCP Training Course on Dispersed Organic Matter. Porto: Plenimagem.

Mendonça Filho, J. G., Menezes, T. R., Mendonça, J. O., Oliveira, A. D., Silva, T. F., Rondon N. F., Silva, F. S. (2012). Organic Facies: Palynofacies and Organic Geochemistry Approaches. In: D. Panagiotaras (Ed.), Geochemistry - Earth's System Processes (211-248). Croácia: InTech.

Menezes, T. R., Mendonça Filho, J. G., Araújo, C. V., Souza, I. V. A. F., Mendonça, J. O. (2008). Fácies orgânica: conceitos, métodos e estudos de casos na indústria do petróleo. Revista Brasileira de Geociências, 38, 80-96.

Neumann, V. H., Assine, M. L. (2015). Stratigraphic proposal to Post-Rift I Tectonic-Sedimentary Sequence of Araripe Basin, Northeastern Brazil. Abstract. $2^{\text {nd }}$ International Congress on Stratigraphy. Graz, Áustria.

Neumann, V. H., Borrego, A. G., Cabrera, L., Dino, R. (2003). Organic matter composition and distribution through the Aptian-Albian lacustrine sequences of the Araripe Basin, Northeastern Brazil. International Journal of Coal Geology, $54,21-40$.

Neumann, V. H. M. L. (1999). Estratigrafia, Sedimentologia, Geoquímica y Diagénesis de los Sistemas Lacustres AptiensesAlbienses de lá Cuenca de Araripe (Noroeste do Brasil). Tesis (Doctorado). Barcelona: Facultat de Geologia, Universitat de Barcelona.

Oliveira, A. D., Mendonca Filho, J. G., Sant'Anna, A. J., Souza, J. T., Freitas, A. G., Menezes, T. R. (2006). Inovação no processamento químico para isolamento da Matéria Orgânica Sedimentar. XLIII Congresso Brasileiro de Geologia, v. 1, 324. Aracaju: SBG. 
Pons, D., Berthou, P. Y., Figueira, J. B. M., Sampaio, J. J. A. (1996). Palynologie des unités lithostratigraphiques "Fundão", "Crato" et "Ipubi" (Aptien supérieur à Albien inferieurmoyen, bassin d'Araripe, NE du Brésil): enseignements stratigraphiques et climatologiques. In: S. Jardiné, I. Klasz, J. P. Debenay (Eds.), Géologie de I'Afrique et de I'Atlantiquesud. C. R. Colloques de Géologie d'Angers, 1994, Angers, France. Bulletin des Centres de Recherches Expbration-Production Elf-Aquitaine, Édition, Mémoire, v. 16, 383-401. France.

Ponte, F. C., Appi, C. J. (1990). Proposta de revisão da coluna litoestratigráfica da Bacia do Araripe. XXXVI Congresso Brasileiro de Geologia, v. 1, 211-226. Natal: SBG.

Ponte, F. C., Ponte Filho, F. C. (1996). Estrutura geológica e evolução tectônica da Bacia do Araripe. Recife: DNPM.

Portela, H. A., Antonioli, L., Dino, R., Garcia, M. J. (2014). Caracterização palinoflorística e paleoambiental da Formação Santana (Cretáceo Inferior), Poço 4-BO-1-PE, Bacia do Araripe, Nordeste do Brasil. Revista Brasileira de Paleontologia, 17(3), 363-372.

Regali, M. S. P., Santos, P. R. S. (1999). Palinoestratigrafia e geocronologia dos sedimentos albo-aptianos das Bacias de Sergipe e Alagoas - Brasil. V Simpósio sobre o Cretáceo do Brasil / Simposio sobre el Cretácico de America del Sur, v. 1, 411-419. Serra Negra: UNESP.
Regali, M. S. P., Uesugui, N., Santos, A. S. (1974). Palinologia dos sedimentos meso-cenozoicos do Brasil I. Boletim Técnico da Petrobras, 17(3), 177-191.

Regali, M. S. P., Viana, C. F. (1989). Sedimentos do Neojurássico-Eocretáceo do Brasil: idade e correlação internacional. Rio de Janeiro: Gávea e Centro de Desenvolvimento de Recursos Humanos Sudeste/ SDRH/Petrobras.

Rios-Netto, A. M. (2011). Evolução Paleoambiental e Palinoestratigrafia do Intervalo Alagoas na parte oriental da Bacia do Araripe, Nordeste do Brasil. Tese (Doutorado). Rio de Janeiro: Instituto de Geociências - UFRJ.

Silva Santos, R., Valença, J. G. (1968). A Formação Santana e sua Paleoictiofauna. Anais da Academia Brasileira de Ciências, 40(3), 337-360.

Tyson, R. V. (1993). Palynofacies Analyses. Dordrecht: Kluwer Academic Publishers.

Tyson, R. V. (1995). Sedimentary Organic Matter: Organic facies and palynofacies. Londres: Chapman and Hall.

Vincent, A. J. (1995). Palynofacies analysis of Middle Jurassic sediments from the Inner Hebrides. Thesis (PhD). Newcastle: University of Newcastle upon Tyne. 